\title{
Implications of the Use of Non-native Trees
}

\author{
for Reforestation on Public Lands in Alberta
}

\section{A Scientific Review}

by

Donald T. Lester

and

Herb F. Cerezke

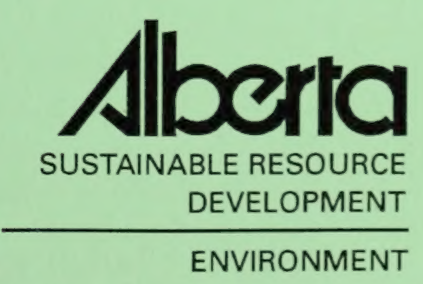





\section{Implications of the Use of Non-native Trees \\ for Reforestation on Public Lands in Alberta}

\section{A Scientific Review}

by:

Donald T. Lester - Genetic Resource Management Consulting

Herb F. Cerezke - Forest Health Consultant

\section{Prepared for}

Land and Forest Service

Alberta Sustainable Resource Development

9920 -108 Street

Edmonton, Alberta

T5K $2 \mathrm{M} 4$

February 2001 
Pub. No. T/002

ISBN No. 0-7785-1781-0 (Printed Edition)

ISBN No. 0-7785-1782-9 (On-line Edition)

Although prepared with funding from Alberta Environment (AENV) and Alberta Sustainable Resource Development (SRD), the contents of this report do no necessarily reflect the views or policies of AENV or SRD, nor does mention of trade names or commercial products constitute endorsement or recommendations for use.

Copies of this report are available from:

\author{
Information Centre \\ Alberta Environment \\ Main Floor, Great West Life Building \\ 9920 - 108 Street \\ Edmonton, Alberta T5K 2M4 \\ Phone: (780) 944-0313
}

or

Alberta Tree Improvement and Seed Centre

Alberta Sustainable Resource Development

Box 750, Smoky Lake

Alberta, Canada

TOA $3 \mathrm{CO}$

Phone: (780) 656-5050 


\section{Executive Summary}

The expansion of international trade and travel, coupled with continuing recognition of serious consequences from introduction of non-native plants and animals, has heightened the awareness of many governments to the need for closer regulation of plant and animal introductions. Although most concern is with insects, diseases and highly invasive plants, it is being realized that the largescale introduction of non-native trees can create problems where they alter native ecosystems. It should be noted that several outstanding successes with introduction of non-native trees are in regions where the indigenous forest has low commercial value for forest products or where there are relatively few commercial tree species. This situation is in contrast to Alberta where large areas of native forest provide the materials for many forest uses and there are several commercially important conifers.

The purposes of this report are to:

$>$ review the general benefits and risks of reforestation with non-native trees,

$>$ note specific potential risks with non-native tree species of current interest in Alberta, and

$>$ to describe decision-making models for regulating the introduction of non-native trees for the reforestation.

In this report, we emphasize shorter-term implications of using non-native trees in reforestation. These are effects for which data are easier to obtain. We recognize, however, that there may be long-term effects on forest ecosystems for which information usually is unavailable.

The benefits and risks from introducing non-native trees are similar, in many ways, to the benefits and risks posed by genetically modified trees. A major difference between the categories, however, should be pointed out. Trees from non-native areas presumably enter their new environment with a genome that has been integrated by selection in the environment of their origin. Genetically modified trees, most often, will have a genome that has been integrated in their local environment except for the gene or genes inserted by the modification process. The consequences from introduction, therefore, may be somewhat different for the two categories. For this reason, and because genetically modified trees follow a specific protocol under federal jurisdiction, this report does not deal with issues around the use of genetically modified trees in reforestation.

This report provides a brief introduction to principles of plant introduction, with focus on the fact that populations of tree species have been molded by selection in their native environments and that success in a new environment is not highly predictable. The historical pattern of introduction usually has begun with introduction for amenity uses and rarely has been accompanied by testing to a standard useful for reforestation. The use of lodgepole pine in Swedish reforestation is an excellent example of a very comprehensive analysis of many impacts by and on the introduced species. Compared with the native Scots pine, lodgepole pine shows benefits for several characteristics and negative impacts for several others. Accumulating experience with lodgepole pine has led to deployment with greater regard for the plantation environment. 
A different example is the use of hybrid poplars in a silvicultural system that has elements more in common with agriculture than with traditional forestry. The exceptional growth potential of many hybrid poplars has led to successful plantations on former agricultural sites in several North American locations. Intensive weed control, early fertilization and, in some cases, irrigation have been required. A changing array of pests has highlighted the necessity of a breeding program to generate new tolerant or resistant clones.

Following a perspective of benefit/risk analysis, benefits are discussed including increased productivity, rapid early growth, and increased or changed quality of forest products, species diversity and gene conservation. Risks are described as genetic contamination of local species, decreased productivity, ecological impacts (short-term and long-term), pests, infection centres, and inadequate production for specific markets.

Eight species or species groups are of some current interest for introduction in Alberta. For these species or species groups, two types of risk for which there is available information, genetic contamination and pest risks are discussed. Note that substantial periods of time may be required before data from which to estimate risk can be obtained. For each tree species or species group, a comprehensive list of major and minor pests in Alberta and in the native environment of the species is given in an Appendix.

Regulatory issues include requirements for testing, weighing the decision to introduce, experimental protocols and deployment. Existing policies and approaches are noted for Alberta, several other Canadian jurisdictions and the U.S.. In the U.S., there has been much recent interest in policy development including processes of decision making. Four protocols for decision making are noted. A preliminary example of a protocol involving estimated benefits and risks is given.

Broader policy issues involve the implications of reforestation with non-native trees for provincial, national and international requirements for sustainable forestry and certification of forest products.

From this review of general issues around reforestation with non-native trees and consideration of reforestation in Alberta, we offer the following conclusions:

1. The existing policy of exclusion for non-native trees in reforestation of public lands has served Alberta well. It has prevented the casual introduction of species that could result in plantation failure as well as genetic and pest problems for surrounding native forests.

2. Despite the usefulness of an exclusionary policy, highly successful use of non-native trees for reforestation elsewhere suggests that a protocol in which benefits and risks are carefully weighed might offer opportunities for enhancement of Alberta's forest resources. 
A protocol for the use of non-native trees in reforestation might include the following elements:

a. formal standards to be met before reforestation with non-native trees would be allowed on public land. Standards might include requirements for testing based on available experience and expected risk. One outline for a decision-making protocol is in Table 1.

b. policies applicable to seed and vegetative materials, as well as deployment. Issues of genetic diversity and self-sustainability, for example, would need to be addressed.

c. a formal plan for monitoring plantation development. Particular emphasis would be on pests and the potential for development of pest epicentres.

d. assignment of liability for negative ecosystem impacts arising from such reforestation. If reforestation with non-native trees results in lowered productivity of public lands, the responsibility for remediation would be specified before reforestation begins. Lowered productivity would include reduced production of non-native tree plantations as well as negative impacts on native forests. In the latter case, responsibility for problems of invasiveness, genetic contamination or pests attributable to non-native tree plantations could extend to public lands beyond the borders of non-native tree plantations. 
Digitized by the Internet Archive in 2016

https://archive.org/details/implicationsofus00lest 
Executive Summary

1.0 INTRODUCTION

2.0 PRINCIPLES OF PLANT GEOGRAPHY

2.1 General:

2.2 Abiotic influences:

2.3 Biotic influences:

3.0 THE HISTORICAL PATTERN OF FOREST TREE INTRODUCTION

4.0 TWO EXAMPLES OF THE SUCCESSFUL INTRODUCTION OF NON-NATIVE TREES

4.1 Lodgepole Pine:

4.2 Hybrid Poplars:

5.0 BENEFITS 8

6.0 RISKS

6.1 Genetic contamination:

6.2 Decreased productivity:

6.3 Ecological impacts:

6.4 Pests:

6.5 Infection centres and risk of spread:

6.6 Inadequate production for specific markets:

7.0 RISKS FROM NON-NATIVE SPECIES OF CURRENT INTEREST IN ALBERTA

7.1 Siberian larch:

7.2 Blue spruce: 13

7.3 Norway spruce: 13

7.4 White X Engelmann spruce: 14

7.5 Red pine: 14

7.6 Scots pine: 15

7.7 Poplars: 15

8.0 REGULATORY ISSUES

8.1 Requirement for testing:

8.2 Weighing the decision to introduce: 18

8.3 Experimental protocols:

8.4 Deployment:

9.0 SOME EXISTING POLICIES IN CANADA

9.1 Alberta: 
9.2 British Columbia: 20

9.3 Quebec: 20

9.4 Ontario: 21

9.5 New Brunswick: 21

9.6 Canada: 22

10.0 POLICY BACKGROUND IN THE U.S. 22

11.0 THE APPLICATION OF DECISION-MAKING METHODS 23

11.1 Formal Analysis: 23

11.2 Protocols: 24

12.0 CONCLUSIONS 24

13.0 REFERENCES (Not all references are cited in the text; many contribute to the lists of pests in Appendix III) 27

14.0 ACKNOWLEDGEMENTS 35

Table

Table 1. A preliminary protocol for approval or rejection of requests for the operational planting of non-native trees 26

Appendices

I. Decision-making chart: sourcing native plant material 36

II. Non-native forest tree species of current interest in Alberta and the extent of testing to date 37

III. Pests of concern for non-native forest tree species of current interest in Alberta 39

IV. A form for request for approval to reforest with planting stock not meeting Requirements 45 


\subsection{INTRODUCTION}

Non-native trees have been planted in Alberta at least since 1911. A summary of planting stock production by the provincial nursery over a 38-year period between 1934 and 1972 shows a total of more than 10 million trees, the most common being identified as ash, poplars, willows and Colorado spruce (Anon. undated). Most of these trees were planted for shelterbelts or ornamental purposes.

For Alberta, reforestation with non-native trees has been of little interest as large areas of productive native forest have been available. Moreover, provincial policy prohibits the use of non-native trees in reforestation. Current concerns over the need to increase forest productivity to meet future needs for wood, coupled with the demonstration that the planting of non-native trees has markedly increased wood production in many parts of the world, have prompted a review of the potential benefits and risks from reforestation with non-native trees in Alberta.

Three categories of trees are included in our definition of non-native: those species that are not native to Alberta, those populations of native Alberta species that violate guidelines for seed transfer, and hybrids in which one or more of the parental species are included in the first two categories.

Although we do not discuss, in detail, the use of populations of native trees that violate seed transfer guidelines, many of the issues are similar to those around non-native species. Guidelines for the transfer of materials for reforestation are intended to insure that future forest are adapted to the environment in which they are established. Populations of native species that violate transfer guidelines presumably are genetically different than those that fit the guidelines even though the differences may be less than for non-native species. Therefore, evidence that such populations are adapted to the areas where they will be used is required. Examples of the issue are noted in Section 7.4 regarding White X Englemann spruce and in Section 7.7 regarding poplars. In both cases, there are issues of uncertain taxonomic status for taxa represented in Alberta.

Some of the issues around non-native trees are similar to those around genetically modified trees (labeled in public discussion as GMO's). A major difference, however, is in adaptation. Non-native trees, as defined here, are adapted to the environment in which they originate. That environment will differ, in varying degrees, from the environment into which they are introduced. GMO's, by contrast, are presumably adapted to the environment in which they will be used and differ from local organisms only by the inserted genetic material.

This report has the following purposes:

review the general benefits and risks of reforestation with non-native trees,

note specific potential risks with non-native tree species of current interest in Alberta, and

$>$ to describe decision-making models for regulating the introduction of non-native trees for the reforestation. 


\subsection{PRINCIPLES OF PLANT GEOGRAPHY}

\subsection{General:}

Among several principles of significance to plant distribution (Cain 1971), three are especially noteworthy for a discussion of non-native species:

a. the distribution of a species is limited by tolerances

b. tolerances have a genetic basis

c. tolerances differ at different stages of development

Environmental factors influencing the success of non-native species usually are classed as abiotic or biotic. The principal abiotic influences are climate and weather. Biotic influences include diseases, competing vegetation, and herbivorous animals including insects.

\subsection{Abiotic influences:}

Trees have genetically regulated patterns of growth that adapt them to specific climates. Initiation of seasonal growth and loss of frost hardiness in the temperate and boreal regions largely is in response to accumulated units of heat above a threshold temperature.

Cessation of growth for some species is in response to shortening daylength and declining temperatures or, in climates with summer drought, to reduced moisture availability.

Matching the climate of a donor region with that of a recipient region is, therefore, an important part of planning for the introduction of non-native species. Hardiness zones have been used for many years to guide the introduction of agricultural and horticultural plants (e.g. Anon. 1965). Complex analyses of weather records have been made to produce maps of "analogous climate" (e.g. Nuttonson 1950).

Recently, the identification of analogous climates has been extended to incorporate adaptedness of tree species. Statistical methods have been used to develop transfer functions that predict the growth and survival of specific populations of trees as they are moved away from their climate of origin (Rehfeldt et al. 1999a). Although originally developed to predict effects of transferring different populations of lodgepole pine in interior B.C., the approach has been extended to performance of Eurasian species of Larix in Alberta (Rehfeldt et al. 1999b).

The influence of soil is also recognized as a factor in adaptation, especially among species. Fertility and moisture availability often are correlated with the presence of specific tree species. The interaction of soil type and competing vegetation, however, can mask species potential for growth. Tamarack, for example, traditionally is found on wet soils with high organic matter. On more upland soils, however, tamarack grows well if protected from vegetative competition in young plantations. Zobel and Talbert (1984) recommended that trees originating on acid soils should not be planted on basic soils and vice versa. They also noted that while many species show high adaptability and will grow on a range of soils, several species of Eucalyptus, for example, show very limited adaptability to a range of soils. 


\subsection{Biotic influences:}

In addition to the joint effects of genes and climate on the success of introduced trees, pests can be an important influence. The pest-host-environment "triangle" is a traditional principle in understanding the potential for disease and insect problems. New host-pest combinations are of particular concern because there has not been an opportunity for evolution of tolerance or resistance in the host species. Competing vegetation is often of less concern as it is frequently suppressed by silvicultural practices in the early stages of plantation establishment. 


\subsection{THE HISTORICAL PATTERN OF FOREST TREE INTRODUCTION}

The introduction of non-native tree species, usually as candidates for ornamental uses, has been practiced for at least the last five centuries (Zobel et al. 1987). Plant explorers would return with a few seeds or seedlings, which were grown by sponsoring botanical gardens or private collectors. A wider distribution might result from noteworthy ornamental qualities or exceptional growth rates.

In Alberta, non-native trees have been planted at least since 1911, mostly for windbreaks (Anon. undated). Plantings for the purpose of species comparisons for reforestation were initiated at least as early as 1920 (Soos and Brown 1970). For many of the early comparative plantings, inadequate experimental design limits conclusions. For example, Scots pine provenance "A", reported by Soos and Brown (1970) to be the most vigorous, appears in a photograph to be located in a border row with little competition on one side. A report from the same period (Anon. 1969), notes that "Only recent planting trials are receiving follow-up surveys to assess successes or failures."

More recently, the importance of seed origin was recognized and, in some cases, systematic experiments that sample both genetic variation of the species and environmental variation in the new environment have been established. Where planting of an introduced forest tree species has reached the scale of commercial application, environmental limits to distribution have become inadvertently evident through plantation failure. Additional limits have been illustrated by exceptional weather events, especially frost, by the joint effects of unfavorable environment and pests, and by pest challenges. Unfortunately, exceptional weather events and substantial problems from pests may not occur until an introduced tree species has been planted over a wide area.

From a scientific perspective, one might say that the introduction of non-native forest tree species for use on a commercial scale represents a series of risks. Risk can be reduced in proportion to the effort and duration allowed in testing but the required effort may be substantial if risk is to be reduced to a level similar to that for native trees. Although different observers have different views of risk, it would seem that the decision to introduce non-native species would require an expectation of very substantial benefits or very low risks to balance a testing effort.

\subsection{TWO EXAMPLES OF THE SUCCESSFUL INTRODUCTION OF NON-NATIVE TREES}

Among many successful introductions in different parts of the world are Monterey pine, several eucalypt species, Sitka spruce, and several pines from the southeastern US. Zobel et al. (1987) tabulated successful introductions particularly in subtropical and tropical regions. It is noteworthy that successful introductions often have been in areas where the native vegetation is poorly suited for commercial wood production or where there are relatively few native forest tree species. 


\subsection{Lodgepole Pine:}

One of the best-researched and documented examples of successful introduction of a nonnative tree species is lodgepole pine in Sweden. The following summary of Swedish experience comes largely from the report of a formal inquiry sponsored by the Swedish National Board of Forestry (von Segebaden 1993). This report was based on observations from 16 specialists from eight different countries and representing different aspects of forestry.

Lodgepole pine was first tested in Sweden in the 1920's. The large-scale introduction of lodgepole pine in the 1970's was a consequence of the recognition that high volume production on a shorter rotation would be needed to alleviate large projected reductions in allowable cut within a few decades. The rationale included the following:

- "superiority in volume production

- uneven age classes of native forests

- hardier and higher plant survival

- survives injuries better than Scots pine

- shortage of local, hardy planting stock"

The forest inquiry of 1973 suggested that lodgepole pine could be used to reforest northern Sweden to the extent of $10 \%$ of the area after 50 years. Parliament, however, directed that the replacement of indigenous tree species should be concentrated where it was difficult to establish native species.

By 1982, early plantation success led to an expansion of the area allowed for lodgepole pine. By 1987, after some years of extreme weather conditions and serious injury to some plantations by the fungus Gremmeniella abietina, allowed planting was reduced by $25 \%$. Two years later, a further reduction of $15 \%$ (bringing the annual area allowed to 23,000 ha.) was established. As of 1992, lodgepole pine occupied from 3 to $5 \%$ of forested areas in northern Sweden mostly on private land.

In the 1960's extensive research resulted in the identification of suitable sources of lodgepole pine seed from the native range in interior British Columbia. The use of suitable seed sources therefore leads to the following average expectations for lodgepole pine in Sweden when compared with Scots pine:

- "higher survival

- better growth

- greater natural mortality

- less bark volume

- lower wood density

- Total added production without bark

$$
\begin{aligned}
\text { appr. } & +2 \% \\
\text { appr. } & +36 \% \\
\text { appr. } & -6 \% \\
\text { appr. } & +8 \% \\
\text { appr. } & -3 \% \\
& +35-40 \% "
\end{aligned}
$$

In addition, lodgepole pine has been:

- less affected than Scots pine for three diseases and more affected by one (perhaps as a consequence of planting in harsher climates)

- less affected by insects 
- more attacked by rodents

- more damaged by deer (in southern Sweden)

- much less damaged by moose

Early vigor results in better plantation establishment, especially in harsher climates and a better ability to survive severe physical injury. The stem of lodgepole is more elastic in early growth and this may lead to poor stem form. Planted lodgepole pine produces sawn timber comparable to planted Scots pine although knot content and drying cracks are somewhat less while strength is somewhat poorer.

Research in the 1980's was focused more on ecological consequences of growing lodgepole pine. Further comparisons with Scots pine include:

- lowered nutrient availability for other forest plants (due to greater growth rate of lodgepole pine)

- lowered light in the plantation; higher humidity

Some of the consequences of these differences are reduced numbers of understory plants and birds. Plant composition (so far) has not changed much except for mushrooms. The habitat for birds and for reindeer is expected to be poorer. In comparing paired stands of lodgepole and Scots pine at ages between 25 and 50 years, Lundmark et al. (1982) found that litter in lodgepole pine stands was more acid, higher in nitrogen and slower to decompose.

A summary of more recent attitudes of commercial forest enterprises toward reforestation with lodgepole pine shows some interesting changes. These changes reflect, in part, a switch from expected shortage of timber to a timber surplus, improved availability of hardy Scots pine seed, and greater interest in spruce. Superior volume production and regeneration, availability of hardy planting stock and lower cost of timber production are reasons for the continued planting of lodgepole pine. The risk of serious plantation failure (fungal injuries), uncertainty about long-term development and ecological consequences, and stem quality are principal concerns.

Perhaps it could be said that the accumulating information and experience are fostering a more targeted view of the role of lodgepole pine in Sweden. For reforestation in Alberta, the Swedish experience provides one model for the scope and direction of questions to be answered before large-scale introduction of non-native tree species may be permitted.

\subsection{Hybrid Poplars:}

The potential for very rapid growth of some hybrids between species of the Aegeiros and Tacamahaca Sections of poplar has been known for more than two centuries (Wright 1962). The introduction of $P$. deltoides from the eastern U.S. to Europe resulted in natural hybrids with the native $P$. nigra. Selected hybrids were propagated and widely distributed in Europe. Some of those early hybrids are still available as clones today. About a century later, artificial hybridization was begun and many thousand clones have been produced since then. Since nearly all poplar hybrids include a species that is non-native, issues discussed in this report are relevant. 
In North America, interest in poplar hybrids has waxed and waned. A large project in the 1920 's produced several outstanding clones that were widely distributed and used in windbreaks and remediation plantings. The availability of large areas of native aspen forest, the relative ease of regenerating aspen forests from sprouts, and the need for intensive maintenance of young plantations of hybrid poplar limited interest in doing the research required to achieve successful hybrid poplar culture on an operational scale. Projections of future fibre needs and examples of yields of high quality fibre have renewed interest in poplar hybrids.

In contrast to traditional silvicultural systems, hybrid poplars are usually grown in systems for fibre production which have elements more common to agriculture. These elements include intensive site preparation, subsequent control of competing vegetation, fertilization and (in some cases) irrigation to standards that compare with agricultural practices. Planting stock consists of clones selected for rapid growth and disease resistance. In earlier approaches in North America, the production of woody biomass to be used as fuel or fibre featured harvest of cuttings or sprouts at ages of one to a few years. The high proportion of bark in such products, however, makes them unattractive for paper manufacture.

Lengthening harvest periods to seven to ten years has resulted in high yields of trees that can be harvested and processed by conventional forestry equipment to provide wood fibre of very high quality. Over the last 20 years, such "silvicultural" systems have been refined to a point where thousands of hectares are in production, some in their third rotation. More recently, there has been interest in adding a few years to rotation length to grow trees large enough for use in the manufacture of lumber. Hybrid poplars have been of most interest in these systems as a consequence of their very rapid growth, ease of propagation, fibre quality, and history of cultivation.

In Canada, large-scale fibre farming with poplar hybrids has been in operation since the 1940's by the Scott Paper Company on the lower Fraser River Delta of British Columbia. The former MacMillan-Bloedel Company initiated fibre farming in the late 1980's and management of that program is now done by Pacifica Papers (van Oosten 2000). For several years, the Ontario Ministry of Natural Resources maintained a large research group at Brockville in support of fibre farming on agricultural lands of eastern Ontario. Fibre farming is being continued in that area by Domtar Papers. In the Northwestern U.S., thousands of hectares of fibre farms are managed on the lower Columbia River floodplain and under irrigation along the Columbia River in the steppe lands east of the Cascade Mountains.

The benefits and risks of hybrid poplar culture have been amply demonstrated in temperate climates. For Alberta, at the northern edge of the Temperate Region and in the Boreal Region, benefits and risks of hybrid poplar culture may be comparable to those less harsh climates. Successful wood production, however, probably will require the support of breeding programs to develop locally adapted clones rather than the importation of outstanding clones from areas further south. The universal failure of outstanding clones from a breeding program at the University of Washington when planted at Prince George, B.C. illustrates the point.

For public lands in Alberta, planting of hybrid poplars currently is prohibited. This policy, combined with silvicultural practices that are similar to agriculture practices in early stand establishment and maintenance, currently will limit interest to private lands. However, as noted in the section on existing policies in Alberta, a statement in The Alberta Forest 
Legacy may be interpreted to support hybrid poplar culture in private woodlots. In addition, a provincial review of tax policy will consider whether privately-held managed woodlots can be treated as agricultural land as an incentive for management. Proposed changes would remove many of the restrictions that currently apply to forestry practices on Crown and private lands (van Oosten 2000).

Successful development of fibre farming with poplar hybrids in Alberta would pose several challenges to a provincial policy for non-native species on public lands. Where private and public lands are in close proximity, there will be risks to forests on public lands. These include gene contamination of native poplar forests, naturalization of nonnative trees on public lands, development of infection centres by pests in poplar plantations, and development of new strains of pests. These risks are discussed in this report under the sections entitled "Risks" and "Risks from Non-native Species of Current in Alberta - Poplars". In addition, it is likely that successful fibre farming on private lands would prompt proposals to extend the approach to some public forest lands.

\subsection{BENEFITS}

a. Increased productivity - Increased productivity is the most common reason offered for the introduction of non-native tree species in reforestation. Adaptedness, adaptability, growth rate, pest tolerance and herbicide tolerance all may be elements contributing to increased productivity. Improvement in a trait such as bark thickness (noted in the comparison of lodgepole pine with Scots pine in Sweden) can add to productivity as well.

b. Rapid early growth - Where liability for reforestation is transferred from licensees to the Crown upon achievement of "free-to-grow" status, there are incentives to reforest with species that have more rapid early growth. This does not necessarily result in increased productivity.

c. Increased or changed quality of forest products - Changes in knot size, wood density, or fiber characteristics could increase the value of forest products. Where conifers replace deciduous species, or vice versa, the quality of forest products is substantially changed.

d. Species diversity - In areas where the number of tree species is low, it might be argued that adding species could result in a more stable ecosystem. This view seems uncertain, however, given the risks associated with the introduction of non-native trees.

e. Gene conservation - Broader distribution of a tree species, especially those with endangered native ranges, could be seen as a benefit in terms of greater genetic representation (Monterey pine is an example). 


\subsection{RISKS}

\subsection{Genetic contamination:}

Pollen of most forest trees of the temperate and boreal zones is carried long distances by wind. This creates the risk of "escape" of non-native genetic material and subsequent establishment of those genes in native populations where compatible species are brought together. The results, theoretically, could be positive or negative. Inadvertently extending some of the risk from introduction of non-native species to native species, however, is not an attractive proposition. One recent example was a proposal to plant lodgepole pine in Saskatchewan where natural interspecific hybridization could transfer the susceptibility of lodgepole pine to eastern gall rust to native populations of jack pine. Studies of pollen transport from seed orchards have shown that buffer zones of several hundred meters can greatly reduce the volume of dispersed pollen but do not contain all of it. Pollen from several forest tree species was collected on a ship 20 kilometres from shore in the Gulf of Finland (Sarvas 1955). For birch, the quantity collected at sea was greater than that collected in pure birch stands. Numerous studies of dispersal from point sources have illustrated the effect of species and topography. Lanner (1966) discussed the implications of autonomous bodies of air called "thermal shells" for long distance pollen transport.

\subsection{Decreased productivity:}

There are several ways in which expectations for increased productivity may be unrealized when non-native species are introduced. Neglecting to account for within-species genetic variation has been a common failing. Decades of research on genetic variation associated with geography and climate have firmly established the importance of identifying appropriate sources of reproductive material for all tree species. Neglecting to choose appropriate environments similarly can result in reduced productivity. Eastern white pine in Europe was considered a successful introduction until planting expanded to a point where blister rust was encountered. The subsequent spread of the disease resulted in cessation of any planting of eastern white pine (Zobel et al. 1987). The potential of several promising non-native species has been tempered by atypical weather, e.g. injury from unusual winter cold and infection by Gremmeniella abietina of lodgepole pine in Sweden or mortality from cold or drought.

\subsection{Ecological impacts:}

Among potential concerns about the consequences of introducing non-native tree species in reforestation are competitive interactions with native species and impacts on soil. While the destructive potential of interactions between native and non-native tree species may be less than that of introduced insects and diseases due to a slower rate of spread, establishment and reproduction of non-native trees can become a nuisance at least locally. For example, 19 introduced pine species are considered to be invaders in South Africa and seed eating insects are being investigated as one means of control. Irradiation of seed to create sterile trees also is being tried (Richardson 1998). In the U.S., Little (1979) listed 69 naturalized tree species including Scots pine, European larch, and Siberian elm. Little did not discuss the degree to which naturalization (natural reproduction in a foreign environment) represents invasion (natural reproduction beyond the immediate area of parents). 
Examples of time lags in spread by natural reproduction of non-native woody species were provided by Kowarik (1995) based on records from Brandenburg, Germany over a period of four hundred years. The range for 19 tree species was from 29 years (black cherry) to more than 374 years (black walnut) with an average of 170 years. The lack of close correspondence of time lags with species fecundity was discussed with reference to a record of rising temperatures and increase in availability of sites for invasion. While the observed time lags may be encouraging from a perspective of immediate problems, they are less positive in terms of continuity in monitoring and in organizational responsibility for introduction.

In addition to concerns about invasiveness of non-native trees as a physical nuisance, there are many potential impacts on other forest organisms and on ecological processes. The example of lodgepole pine is Sweden (Section 4.1) illustrates the point. Another example would be where site conversion changes a coniferous forest to a deciduous forest or vice versa. There, significant change in wildlife habitat, soil chemistry and nutrient cycling would be expected.

\subsection{Pests:}

Views on the risks of pests with non-native tree species have varied widely. In the early years after introduction, some species have benefited from escape from pests indigenous to their native environment. Conversely, trees in new environments may be more susceptible to new pests because they have not had the opportunity to evolve genetic tolerance. According to Zobel et al. (1987), "The newly established exotic may be initially pest free, but it rarely fails that some pest will sooner or later attack it." The same authors suggest that genetic variation is available to ameliorate most pest problems and that a tree-breeding program may be a necessary condition for successful introduction.

Liebhold et al. (1995), by plotting the cumulative number of non-native insects and mites introduced into the United States since 1600, show that the number has increased exponentially over the last 200 years. They suggest that the acceleration is likely to continue, given trends in human demography.

For purposes of assessing insect and disease risks before deciding to introduce a tree species, insects and diseases might be classified in four categories, major and minor pests native to the range of the tree species and potential major and minor pests native to the area where the tree species will be introduced. To some extent, these categories of risk can be estimated. More difficult to assess is the case where harmless pests might become harmful. An example of this category is Dothistroma pini on Monterey pine. That disease is considered a nuisance in the native habitat of Monterey pine but has created a loss of confidence in plantation forestry with Monterey pine in several countries following severe plantation mortality (Zobel et al. 1987). Although it is not clear why the host- parasite relationship has changed, warm, wet summers in some of the new environments are a suggested factor. Serious pests that are indigenous to neither the native nor the new environment also have been found.

Niemela and Mattson (1992) noted that insect pests of European origin have invaded North America far more often than the reverse. The greater diversity of North American flora may be one factor. The possible benefit of non-native tree species through increased biodiversity might thus be uncertain. 
The introduction of non-native tree species into new habitats provides a risk for attack by native insect, disease and other tree pests because they are exposed to indigenous pests not usually encountered. Some native pests may readily exploit new tree hosts, often with severe consequences. The behavior of fungal pathogens and insect pests on new non-native hosts is often unpredictable. A major consideration in the success of non-native tree introductions relates to their susceptibility to attack and potential as hosts for life cycle development (Zobel 1982). Non-native species and hybrids are generally deployed in evenaged plantations at a uniform spacing, may have a reduced genetic base, and usually will be subjected to environmental and stress conditions that differ from those of their native habitat. If susceptible, such plantation conditions can favor the intensity and spread of certain pests: e.g., Warren root collar weevil in plantations (Cerezke 1994) and Armillaria root disease (Shaw and Kile 1991). In some cases, non-native tree species show greater susceptibility to attack than native hosts do. For example, Scots pine plantations in southern Manitoba and Ontario were attacked by pine root collar weevil (Hylobius radicis) more severely and had higher percentage mortalities than did native hosts (Cerezke and Pendrel 1995). Similarly, cuttings of Populus deltoides and its hybrids have suffered from severe infections of leaf rust disease (Melampsora medusae) and a canker disease (Cytospora chrysosperma) (Hepting 1971).

Examples of the reverse situation are also numerous and well known, where native tree species show high susceptibility to introduced non-native pests. Such well known cases include American elm susceptibility to Dutch elm disease; western white pine, limber and whitebark pines' susceptibility to white pine blister rust; and red pine susceptibility to European pine shoot moth. The recent introduction into Nova Scotia from Europe of the brown spruce longhorn beetle (Tetropium fuscum) and its subsequent killing of live red spruce further demonstrates the unpredictable nature and risks of such alien introductions. In its native habitat on Norway spruce, this insect is not likely to attack healthy trees. In a recent pest risk assessment report on unprocessed Siberian larch log imports into the United States, it was concluded that up to five major non-native insect and disease pests could be introduced into North American forests (Goheen and Tkacz 1995). The consequences of potential establishment and spread of these organisms cannot be fully realized.

In trembling aspen forests, a north-south gradient in susceptibility to Hypoxylon canker disease was observed as well as variation between clones in decay characteristics (Wall 1969, 1971: Copony and Barnes 1974; French and Hart 1978). Many insect and disease pests also show higher selectivity on young shoots and tissues compared to older tissues, suggesting developmental changes in defensive chemistry as trees mature. Some examples include leaf and twig blight (Venturia spp.), the leaf-feeding beetle, Chrysomela confluens, and aphid spp. (Hiratsuka et al. 1995; Whitham et al. 1996). In natural hybridization zones of two sympatric Populus species ( $P$. angustifolia $x$ P. fremontii) it was demonstrated that insect and fungal species were more abundant and occurred at higher population densities than was the case in adjacent stands of either parent host species (Whitham 1989; Whitham et al. 1996). It was suggested that the zone of hybridization acted as a "sink" for greater numbers and survival of insect and fungal organisms. From a positive perspective, natural hybridization created greater biodiversity of species including more avian and small mammal species. It may be speculated that plantations of introduced hybrid species may, in time, provide similar increased biodiversity, including more pest species risks. 
New research findings have discovered the development of natural hybrid pathogens such as poplar leaf rust disease. The rust species, Melampsora medusae, which occurs mainly on Populus deltoides in eastern United States crossed with $M$. occidentalis, which infects $P$. trichocarpa and $P$. balsamifera in western U.S. and Canada. The new hybrid ( $M$. medusae $\times M$. occidentalis) thus receives genomes from both parents and has the potential for enhanced pathogenicity (Brasier 2000; Newcombe et al. 2000). Other closely related fungal species, when brought together, have developed similar hybrid forms with enhanced pathogenicity. The process can develop over relatively short periods of time. The development of hybrid fungal pathogens adds to the risks of introduced tree hosts and pest species.

\subsection{Inadequate production for specific markets:}

Where wood produced by non-native species requires changes in processing facilities or in marketing, there may be a minimum threshold of production to reach economic feasibility. This requirement will, in turn, influence the size of a reforestation program and the degree of associated risk.

\subsection{RISKS FROM NON-NATIVE SPECIES OF CURRENT INTEREST IN ALBERTA}

Appendix II lists tree species for which there is some current interest in introduction and notes the extent of testing. Appendix III gives some of the anticipated risks from pests for these species. Following are brief comments on potential risks posed by introduction of these non-native trees. It should be kept in mind that new environments may allow much different relationships for species crossability and for host-pest relationships.

\subsection{Siberian larch:}

Genetic contamination: Information on the ability of larch species to hybridize is abundant for a few species combinations and unavailable for many combinations. Hybrids between Siberian and European larches have been of interest in Finland (Wright 1976) but the native tamarack has not been included in most attempts at interspecific hybridization. While it has been suggested that the Eurasian larches may have difficulty hybridizing with North American species (Jaquish pers. comm. 2000), the potential for crossing needs to be determined. Some evidence may be available in existing Siberian larch plantations in Alberta.

Pest risks: Established plantations of Siberian larch in Alberta since 1980 suggest there are presently few serious native pest species. Most important to date are Armillaria root rot and larch sawfly. The risk of Armillaria infection may relate to the planting of Siberian larch on clearcut sites of previous old growth stands. There is currently little information to indicate whether Siberian larch is more susceptible to native Armillaria spp. than are its native conifer hosts. Snowshoe hare could also be very damaging during its peak cycle years, especially in sapling size stands. Stem girdling injury by porcupines is likely to be common in some areas. Accidental introductions of non-native pests such as larch canker disease, European spruce beetle, Asian gypsy moth, nun moth and the root rot disease, Heterobasidion annosum would be considered as major risks, not only for Siberian larch but also for some native coniferous and deciduous species. 


\subsection{Blue spruce:}

Genetic contamination: Artificial hybrids with white spruce have been reported by several authors. Results from the most comprehensive controlled crossing of blue and white spruce were reported by Bongarten and Hanover (1982). Their data, shown below, provide a rough estimate of the potential for genetic contamination, at least in the environment where the crosses were made. Although the hybrids grew well in Michigan plantings, the risk of genetic contamination from plantations of limited may be judged as real, but low.

\section{FILLED SEED PER CONE}

Female Parent

\section{Male Parent}

Blue Spruce
2.7

30.4

In natural stands, individuals with morphology intermediate between blue and Engelmann spruce also have been described (Hanover 1975). Ernst et al. (1990) studied spruces in an elevational transect that provided a transition from predominantly blue to predominantly Engelmann spruce. Chemical analysis of more than 100 individuals from a zone where individuals of both species were intermingled failed to identify any trees with hybrid characteristics. A large program of interspecific crosses between trees in the same transect resulted in a seed germination of $0.3 \%$, all when Engelmann spruce was the maternal parent. Although the seedlings were verified as interspecific hybrids, many showed abnormal germination and only $60 \%$ survived. These research results suggest that the potential for genetic contamination between blue and Engelmann spruce is very low.

Pest risks: Blue spruce has been widely planted on the Canadian prairies as an ornamental landscape and shelterbelt species over the past 80 to 100 years. Native pest species attacking blue spruce in these situations are well documented, but some of the pests may behave differently in forest planting situations. Pests of high risk would likely include yellowheaded spruce sawfly, white pine weevil, Armillaria root disease, snowshoe hare, and the spruce budworm in certain regions of the province. Other pests causing less severe injury could be important during certain years, in localized regions or during different phases of tree growth (see App. III). Behaviour and importance of some other pests, both native and non-native such as scleroderris canker and fomes root rot disease are likely to be significant but their potential importance is difficult to predict.

\subsection{Norway spruce:}

Genetic contamination: Wright (1955) describes crossing between Norway spruce and black spruce as "moderately successful". Direct crosses between Norway and white spruce are described as unsuccessful although five Asian species seem to have a potential for "bridging" the crossing barrier. The potential for genetic contamination from Norway spruce thus seems to be mixed and an evaluation of attempts to cross with white spruce would be a required first step, possibly followed by additional experimental work. 
Pest risks: Pest risks for introduced Norway spruce are likely to be similar to those for blue spruce, and include the current important pests on native white spruce: e.g., white pine weevil, spruce budworm, yellowheaded spruce sawfly, Armillaria root rot and tomentosus root rot. As with other spruce species, damage by white pine weevil and yellowheaded spruce sawfly are most important in young stands. Root pathogens such as Armillaria ostoyae, Inonotus tomentosus, Phellinus pini and Phaeolus schweinitzii may also be important during different phases of tree growth and on different site conditions. In Scandinavian countries, the root and butt diseases, Heterobasidion annosum and Armillaria spp. cause severe economic losses to Norway spruce, of which the former is the most serious (Ronnberg and Jorgensen 2000). The S-form of this root rot fungus (also found in United States and in British Columbia; Allen et al. 1996) may infect trees of all ages, with infections occurring primarily through root wounds and cut stumps. In this sense, trees with associated root and root collar girdling wounds made by Hylobius weevils could be significant in Alberta forests for promoting this disease (Cerezke 1994). Norway spruce is also susceptible to the European strain of scleroderris canker disease, which is now present in Ontario (Myron et al. 1994).

\subsection{White X Engelmann spruce:}

Genetic contamination: The ability of white spruce to hybridize with Engelmann spruce is well known. The extent of apparent natural hybridization, combined with a similarity of performance in the nursery and plantation, has resulted in the operational appellation "interior spruce" for a taxon that may include gene combinations representing white spruce and varying degrees of Engelmann spruce. It seems certain that "interior spruce" introduced to Alberta, and grown in proximity to native white or Engelmann spruce, could transfer genes to the native populations. Whether this would have any negative consequences is uncertain. Little (1979) also lists natural hybrids of white spruce with black spruce and Sitka spruce. The latter hybrid is well known in the lower elevations of the transition between coastal and interior climates where river valleys pass through the Coast Range of B.C.

Pest risks: There are no known risks of this hybrid as an introduced non-native tree that would be different from present native stands in Alberta of either white spruce or Engelmann spruce (Coates et al. 1994). Any additional risks to pests will likely relate to the sites and locations of planting and perhaps to features of plantation characteristics.

\subsection{Red pine:}

Genetic contamination: For taxonomic purposes, the genus Pinus is divided into several Sections. Successful controlled crosses are far more common within than between Sections (Duffield 1953). Although extensive crossability studies have not been conducted with red pine, the failure of all attempts at interspecific hybridization within the Section that includes red pine suggests that the potential for genetic contamination is nil. No natural hybrids have been reported.

Pest risks: In eastern Canada and the United States, red pine is highly susceptible to a number of seedling diseases, including scleroderris canker disease (Hepting 1971; Myren et al. 1994). Both of the strains of scleroderris canker, North American and European, occur in Ontario and both readily infect young red pine and have caused seedling mortality in nurseries. In Ontario and Manitoba, Armillaria root disease has caused severe losses in 
red pine plantations, while the root rot fungus, Heterobusidion annosum, if introduced into Alberta, has the capacity to kill residual trees in thinned plantations. Two non-native insect species that could be important include the European pine shoot moth (present in interior B.C.) and the pine shoot beetle (Tomicus piniperda) that is now present in southern Ontario, are potential pests in Alberta.

\subsection{Scots pine:}

Genetic contamination: Duffield (1953) reported that attempted crosses of Scots pine with seven other species were failures. Crosses with lodgepole pine, both as male and female parent were included in those failures. Genetic contamination from introduced Scots pine is, therefore, unlikely.

Pest risks: The planting of Scots pine has had a long history on the Canadian prairies, both as an amenity tree and in experimental plantations. Young plantations established in southern Manitoba were highly susceptible to jack pine budworm, root collar weevils, Armillaria root rot, and to some extent, terminal weevils and shoot moths. In southern Alberta, 40-60 year old Scots pine planted in parks, shelterbelts, and in a plantation were vulnerable to mountain pine beetle and suffered high mortality. Other native pests that could rate from low to high risk in certain areas of the province include pine stem rusts, western gall rust, defoliating sawflies, pine needle cast, snowshoe hare and porcupine.

The list of pests not native to Alberta that can be considered of low to high risk for causing damage to Scots pine is given in App. III. Species such as scleroderris canker North American and European races), a pine shoot beetle, and annosus root and butt rot may present the highest risk because they already occur in other parts of Canada. The poplar leaf rust, Melampsora pinitorqua, is worthy of mention since it is one of the few poplar rusts that causes more severe injury to its alternate host (Scots pine) than to its poplar host (P. tremula).

\subsection{Poplars:}

Genetic contamination: The genus Populus is divided into six taxonomic sections. The aspens and white poplars are included in the Section variously named Leuce (e.g. Dickmann and Stuart 1983) or Populus (Eckenwalder 1996), cottonwoods are in the Sections Aigeiros and Tacamahaca. Artificial crosses within Sections are generally easy to make and natural hybrids often are common where species are in contact.

Aspens and hybrids - Within the Section Populus, natural hybrids between sympatric species have been identified and controlled crosses between species from different continents have been used in commercial production. Taxonomic classification within sections, however, may not be indicative of substantial genetic differences usually thought to be typical of species. From field observations, it has been suggested that $P$. tremuloides, tremula, and davidiana may represent geographic variants of a single circumpolar species (Stettler, pers. comm. 2000). Whether the non-native taxons are variants or species, their response to new habitats, and especially to local pests, would have to be tested.

Controlled crosses between the Section Populus and other Sections of the genus have been unsuccessful or made with great difficulty. Genetic contamination of the native trembling aspen thus is of potential concern whereas contamination of the native balsam poplar is 
less likely. The observation that in north central Alberta, occasional trees are found that defy assignment to either aspen or balsam poplar (Larocque pers. comm. 1993) and the listing by Little (1979) of natural hybrids of trembling aspen with cottonwoods and balsam poplar suggest that genetic contamination is possible. Ronald (1982) produced several hybrid families from crosses between aspen and cottonwoods or balsam poplars although many hybrid seedlings were weak and soon died.

Hybrid Poplars - The term "hybrid poplar" is commonly used in reference to hybrids among and between the Aigeiros and Tacamahaca Sections. Hybrids, from both natural and controlled crossing, between species in these different Sections are common and of great interest in tree improvement. Natural hybrids were identified in Italy more than 200 years ago and controlled crossing among species within and between the two Sections has provided outstanding trees for plantations. The introduction of species or hybrids of the cottonwoods or balsam poplars thus would be expected to have a high potential for genetic contamination of the native balsam poplar as crossing and natural regeneration are likely.

Some empirical evidence is available. In an attempt to estimate the potential for escape of genes from genetically engineered cottonwood, DiFazio et al. (1999) surveyed the presence of non-native genes in seeds and seedlings collected near plantations of cottonwood hybrids. At two locations, genes from hybrid males were represented in up to $3.8 \%$ of seed collected from native cottonwoods. Seed traps placed adjacent to hybrid plantations yielded an average of $18 \%$ of trees with genes from the non-native source and plots treated to encourage seedling establishment had an average of $42 \%$ of seedlings with genes from the non-native source. In natural stands in the vicinity of hybrid plantations, however, from 0 to $1 \%$ of the seedlings showed evidence of gene flow. The authors concluded that due to "stringent habitat requirements, opportunities for establishment are rare". The relationships between riparian habitats and cottonwood seedling establishment, as described by Braatne et al. (1996), suggest that despite the rarity of opportunity, substantial gene escape could occur in riverine locations with the coincidence of seed release and a favorable environment. Braatne et al. (1996) note that establishment of cottonwood in nonalluvial habitats commonly occurs when moist mineral soils are available in adjacent agricultural fields and forest clearings.

Pest risks: Tree species in the genus Populus naturally support a wide variety and diverse group of fungal pathogens and insect herbivores. On trembling aspen ( $P$. tremuloides) alone, at least 300 species of insects derive food and sustenance from its live tissues, and as well, more than 250 species of fungi are known to be associated with its decay (Newcombe 1996; Whitham et al. 1996).

The community of insect and fungal species associated with Populus varies between species and also intraspecifically between hybrid forms. Many species of fungi and insects are host-specific while others are more inclusive and may exhibit specificity within a section, a subsection, or the entire genus (Newcombe 1996). Within a "susceptible species" of Populus, the response of individual trees to a fungal pathogen may also vary from one of resistance to one of being susceptible. Many insects and fungal pathogens may be more problematic on young trees and stands, while other species more commonly attack older stands. Some fungal pathogens such as Melampsora leaf rusts have become widely distributed as a result of the expansion and movement of hybrid poplar cultures. 
The selection and breeding of Populus species for resistance to pests has largely been one of interspecific hybridization and clonal selection, and has been a major thrust around the world (Newcombe 1996). In most regions where poplars are grown, leaf and stem diseases have generally exhibited the greater risk, limiting tree performance and wood fiber yield (Ostry et al. 1989). Fifteen years of experience with cottonwood hybrid plantations on the lower Columbia River in Oregon suggest that genetic adjustment of Melampsora spp. to clones selected for resistance is rapid and a large breeding program is required to maintain resistance levels for high wood productivity (pers. comm. Stanton 2000). By contrast, clones selected for resistance to Venturia spp. maintain that resistance for a longer period.

Aspens and hybrids - Species of insects and fungal pathogens listed in App. III are categorized by potential risks for aspen/hybrid hosts introduced into Alberta. Among the species of the Populus (or Leuce) section, several native pests pose a high risk to long term growth and survival, and include the forest tent caterpillar, stem stains and decay fungi such as Peniophora and aspen trunk rot, Armillaria species, and Hypoxylon canker disease. Of somewhat lesser risk are such defoliators as large aspen tortrix and Bruce spanworm. Aspens grown in rows with open spacings may be more prone to attack by wood boring species, the damage of which has been linked to incidence of Hypoxylon canker. In young regeneration, the aspen leaf and shoot blight fungus may cause severe losses, requiring the selection of resistant clones.

The native leaf rust fungus, Melampsora albertensis, specific to trembling aspen, has recently been re-described as a form of M. medusae that infects Populus deltoides in eastern North America (Callan 1998). While this rust in Alberta causes only minor defoliation of aspen, it contributes more significant injury to seedlings of its alternate coniferous hosts, especially Douglas-fir and Larix species. Non-native Melampsora species (see App. III) could impose similar risks if introduced into Alberta. Of more serious concern is a bacterial canker disease, presently restricted to Europe that infects branches and stems of all species of Populus (Ostry et al. 1989).

Hybrid Poplars - Among the native insect pest species listed (App. III), all may be considered of low to moderate risk for tree injury. These include the forest tent caterpillar, leaf beetles, and two introduced pests, the satin moth (a defoliator) and the poplar-andwillow borer. The latter species may girdle or riddle stems of young trees and is of most concern in plantations and nurseries.

Important diseases contributing economic losses due to stem decay include Armillaria species and a Ganoderma species causing heart and butt rot. For cottonwoods grown in short rotation, these diseases may have less significance. Several foliar and shoot diseases are common among cottonwood species. Linospora leaf blight, Septoria leaf blight and a leaf rust appear to be the most important and can cause premature defoliation and reduced growth and yield. Alternate hosts required for the leaf rust include species of Abies, Larix, Picea, Pinus and Pseudotsuga. Introduction of other Melampsora species onto cottonwood and hybrid leaves provides ideal conditions for the development of pathogen hybrids.

In western Canada, Septoria leaf blight infections result in leaf spots, while in eastern Canada and the United States, they may be associated with severe stem canker damage on $P$. deltoides and some hybrids. Of the non-native pests, high risks would be associated with the bacterial canker and with Septoria canker diseases. Introduction of any of the nonnative leaf rusts could be equally damaging. 


\subsection{REGULATORY ISSUES}

\subsection{Requirement for testing:}

Despite the increasing availability of sophisticated models for matching climates, the potential of non-native species can only be determined by testing in the new environment. The number and variety of native forest tree species here have made North America a donor of species rather than a recipient. Zobel et al. (1987) note that although many nonnative species are popular for ornamental use, most native species outgrow introductions and therefore are of little interest in reforestation. The period required to assess many types of ecological impact would be much longer than testing for growth rate.

In many respects, interspecific hybrids pose issues similar to species introduction. Although hybrids among conifer species often are intermediate in adaptation, the desirability of intermediate traits may depend on the environments chosen for planting. A classic example is the pitch pine - loblolly pine hybrid in South Korea (Hyun 1976). The cross is intended to combine the cold hardiness of pitch pine with the vigor and stem quality of loblolly pine. At the south end of the Korean Peninsula, climate has allowed loblolly pine to be grown, in the central portion of the country, the hybrid is best, and in the North cold injury is greater on the hybrid than on pitch pine.

Poplar hybrids present a different picture. Species combinations in which the hybrids far exceed either parent in growth are well known for both aspens and cottonwoods although, again, the environment chosen for planting is important. Hybrids between $P$. tremula and $P$. tremuloides have been used on a commercial scale in Scandinavia and various cottonwood hybrids form the basis for poplar culture in Canada, the United States and Europe. Cottonwood hybrids well adapted to the Pacific Coast and irrigated areas east of the U.S. Cascades and as far north as Kelowna, B.C., however, have been quickly killed by cold at Prince George, B.C.

\subsection{Weighing the decision to introduce:}

In addition to climate analogues as a basis for trial introductions, there have been analyses of the life history attributes that are common to invasive tree species. Rejmanek and Richardson (1996) classified 24 pine species as invasive or non-invasive based on reports on natural spreading on two or three continents where they have been planted. They then chose 10 attributes of life history that are likely to influence invasiveness. A discriminant analysis was used to weight attributes between the two categories. Three attributes made major contributions to maximizing the difference between the two groups. A table of general rules for identifying the potential invasiveness of specific pine species was developed. A similar approach with 180 species of woody plants in North America resulted in development of a decision tree that could be used to acceptance or reject a proposal to introduce a given species (Reichard and Hamilton 1997). Presumably, similar approaches could be developed to assess the risks from non-native pests. Liebhold et al. (1995) have suggested some attributes of invasive forest pests and vulnerable environments but have not provided the analytical results needed to establish a decision framework.

From a broader perspective, a decision-making chart (Appendix I) has been developed to guide the choice of plant material for revegetation of disturbed sites in Alberta (Native 
Plant Working Group 1999). Although emphasis is on native plants, 16 non-native species are acceptable and the definition of "native" includes potential sources of material substantially distant from the site to be revegetated. For "Forest Trees with Novel Traits", a sequence of questions and decisions for initial screening of requests for introduction has been proposed (Anon. 1999a).

\subsection{Experimental protocols:}

Where benefits from introduction of a non-native species seem to outweigh risks, a general protocol could be developed to provide information required for approval to reforest with a non-native species. Such a protocol could be flexible enough to accommodate different levels of expected risk. Among the elements to be included might be the following:

- anticipated benefits (including expected products)

- identifiable risks (including extant and potential)

- sampling plan for the species

- sampling plan for the new environments

- experimental planting design (including controls)

- plan for isolation (if necessary)

- documentation

- plan for evaluation of tests

- reporting

- duration of testing phase

- anticipated scope of successful introduction

\subsection{Deployment:}

Where evidence is adequate to approve reforestation with a non-native species, there may be regulatory issues around how that species is deployed and how plantation development is monitored and reported. An approval for reforestation might be unconditional or conditional with restrictions applying to the location, size or distribution pattern of plantations. Presumably, plantations with non-native species would have monitoring and reporting requirements that are higher than for native species.

\subsection{SOME EXISTING POLICIES IN CANADA}

\subsection{Alberta:}

The deployment of non-native trees for reforestation of public lands is regulated through the requirements that tree species must be chosen from an approved list and the deployment of seed or vegetative material must fit within seed transfer guidelines. Currently, the only non-native trees on the approved list are Siberian larch and hybrid poplar (Anon. 2000). These exceptions were included as a matter of administrative convenience so that existing small "operational demonstration plantings" would not be lost in inventory. It is not currently intended that additional plantings of these non-native trees will be allowed on public land. Non-native trees may be allowed for experimental plantings of limited area. 
On private lands, at least in one case, trial plantations of "imported deciduous stock" are part of a Forest Management Agreement (Thomas 1998). With reference to woodlots (private), The Alberta Forest Legacy states that "The Government of Alberta and the wood products industry will encourage the development of sustainable woodlots in the province as an economic option for private landowners, as market conditions warrant." It is not clear from this statement whether "sustainability" carries the same meaning as in provincial policies for seed and vegetative material and for deployment of genetically improved planting stock for reforestation on public lands.

For land reclamation using "lesser" vegetation, emphasis also is on native species (Oil Sands Reclamation Committee 1998; Native Plants Working Group 1999). Non-native species, however, may be used under certain conditions (Native Plant Working Group 1999). Problem species, including some native species, are identified and their use is considered to violate the guidelines. Note that "native" plant material "from a known source in Alberta or a comparable natural subregion in Canada or the United States" may be acceptable. Although the guideline document defines the terms "provenance" and "source-identified", the genetic implications of provenance seem to be overlooked.

\subsection{British Columbia:}

The deployment of non-native trees for reforestation is regulated through the requirement that all seed and vegetative material for reforestation of Crown lands must be registered. Registration, in B.C., is synonymous with approval for use because each seedlot or vegetative lot must meet guidelines (seed planning zones and transfer guidelines) developed to ensure adaptation. Non-native trees will not be planted on Crown lands, therefore, except on an experimental basis or after trials have adequately established a performance record. A copy of the form for requesting a variance in use of seed or vegetative material is in Appendix IV. Several variances to the policy are specified in the Seed and Vegetative Material Guidebook (Anon. 1995). Experimental results are considered adequate to allow superior provenances of lodgepole pine, interior spruce, and Sitka spruce in specified areas that are out-of-guideline. Similarly, seed of noble fir, western white pine and Sitka spruce from specified areas in the U.S. can be used within specified areas of B.C. For cottonwood hybrids, a list of approved clones judged suitable for specific areas, as determined by a formal Ministry testing program, is available.

The deployment of non-native trees is further subject to regulation through standards for achievement of free-to-grow status as indicated by the following quote "Extended free growing time frames are also recommended to manage the risk associated with the uncertainty of long term performance of exotic species" (Anon. 1999b). The decision to extend a time frame rests with a district manager and must include supporting evidence. The intent of the option for extended time is to allow plantations to be tested by abiotic or biotic challenges that may not occur within time frames for free-to-grow for native species.

\subsection{Quebec:}

The use of non-native trees is not regulated in Quebec but all stock for reforestation is produced by the Ministry of Natural Resources so that reforestation is centralized. Deployment of native species is based on availability of stock for specific areas to be reforested. Decisions on deployment follow a hierarchy where improved stock of appropriate geographic origin is the first choice. If improved stock is unavailable, stock is 
chosen from the same ecological sub-region or from increasingly broad ecological classifications that include the area to be reforested. An increased level of risk is recognized as the level of ecological classification broadens.

The use of non-native species has not been questioned in Quebec but is expected to be soon. Currently, reforestation with non-native species includes Norway spruce, hybrid larches, and hybrid poplars, all at annual planting levels between 1 and 2 million trees. Non-native trees comprise about $5 \%$ of annual planting in Quebec. Norway spruce was planted at an average level of more than 5 million trees for several years but numbers have been markedly reduced since outbreaks of weevil.

Forest policy currently is under review and it is expected that the use of non-native species, as well as improved native species will be subjects for discussion this year.

\subsection{Ontario:}

For native species, Ontario utilizes a system of climatically-based seed zones. Policy is limited to the requirement that all seed of native species shall be identified by seed zone of origin. Where that is the only information available, the seedlot can be used only in the seed zone of origin. Where geographic coordinates are available, seed may be moved to areas of similar climate. Seed is not registered in Ontario but Forest Management Plans must identify how licensees will meet seed requirements.

For non-native species, requests are handled on an individual basis. To date, the one request has been managed with an introduction plan to increase the probability that introductions (hybrid poplars) will survive trials to screen for adaptability. The emphasis in Ontario, so far, seems to be on education and facilitation to improve the probability of success. It is recognized, however, the introduction of non-native species poses potential risks to native trees. This issue is currently approached by comparing the extent of introduction with the distribution and abundance of native species. Displacement of rare native species by non-native species would be avoided by preventing the planting of nonnative species in habitats where rare species occur.

The risk of genetic contamination from non-native species would be treated in terms of probability as a function of effective population size of both non-native and native trees. Elements in the estimation of risk would include relative numbers of native and non-native trees, cross compatibility and expected isolation. An example is Norway maple where large-scale planting is unlikely, hybridization with the native sugar maple is highly likely, large seed crops are frequent, and shade tolerance increases the probability of seedling establishment.

\subsection{New Brunswick:}

The issue of non-native species in N.B. has been relatively minor since Norway spruce is the only non-native species that is used in reforestation. Norway spruce has been a part of reforestation for so long that it is considered to be nearly a native. Provenance and progeny tests have been in place for many years. Spruce weevil is a problem and tolerant/resistant genotypes have been included in seed orchards for Norway spruce seed production. N.B. controls stock for reforestation on Crown lands through Provincial facilities for seed extraction, storage and growing of seedlings. For New Brunswick's largest forest 
company, the use of Norway spruce currently seems to be somewhat self-limiting as a consequence of availability of high quality orchard seed of the native white spruce and an apparent lack of advantage in wood quality of Norway spruce (Adams, G. pers. comm. 2000).

The question of non-native species has come to the N.B. Tree Improvement Council in relation to certification of forest practices.

\subsection{Canada:}

Recognition that the introduction of non-native species is of national interest is reflected in Canada's National Forest Strategy. The Canadian Council of Forest Ministers lists "area and severity of occurrence of exotic species detrimental to forest condition" as one of the indicators of maintenance and enhancement of forest ecosystem condition and productivity (Canadian Council of Forest Ministers 1995). In addition, The Canadian Biodiversity Strategy recommended, as a strategic direction, to "take all necessary steps to prevent the introduction of harmful alien organisms and eliminate or reduce their adverse effects..." (Biodiversity Working Group 1995).

Proposed Federal policy on non-native trees is centered on "Forest Trees with Novel Traits" (FTNT's). FTNT's are defined as "A forest tree/genotype possessing characteristics that demonstrate neither familiarity nor substantial equivalence to those present in a distinct, stable population of a cultivated species of seed in Canada and that have been intentionally selected, created or introduced into a population of that species through a specific genetic change" (Anon. 1999a). Norway spruce in New Brunswick, as an example, would seem to be "familiar", and probably "substantially equivalent." The criterion of "a specific genetic change" might be more difficult to interpret. Although this proposal was developed mainly for regulation of release of GMO's, the accompanying "Safety-based Model for Regulation of Forest Trees" requires that key issues of environmental impact by non-indigenous species shall be addressed.

Even though Federal jurisdiction has precedent, Federal-provincial cooperation would seem to be the appropriate model. The proposed regulatory steps in risk assessment of Forest Trees with Novel Traits include a requirement that approval for commercialization shall "comply with Provincial regulations". This requirement, however, occurs after approval for unconditional release. Experience in the U.S. suggests that much can be accomplished within a cooperative framework although conflicts can be expected to arise, especially with non-native species in and around protected lands (U.S. Congress 1993).

\subsection{POLICY BACKGROUND IN THE U.S.}

Although reforestation with non-native trees was not addressed, official concern about the introduction of non-native organisms was well documented in "Harmful Non-indigenous Species in the United States" (U.S. Congress 1993). Nevertheless, as of 1997, the U.S. was following a policy of allowing all introductions unless invasiveness had been proven. Liebold et al. (1995) stated that "Development of a set of principles and guidelines for importation of exotic plant species should be a high national priority." Executive Order 13112 on Invasive Species, signed in 1999, represents recent action to address part of the problem. The Order seeks to prevent the introduction of invasive species, and to provide 
for their control and minimize their impacts (Corn et al. 1999). These goals are to be achieved by coordinated efforts of federal agencies through a National Invasive Species Management Plan developed by an Invasive Species Council. The Council also is directed to develop recommendations for international cooperation, promote a network to document and monitor invasive species impacts, and to develop an information system on invasive species. Legislation has been introduced to expand the responsibilities of the Animal and Plant Health Inspection Service, to facilitate the listing of any weed of regulatory concern, and to increase penalties for violations. Federal-state relationships pose a particular challenge, in part, because the authority for preemption varies among categories of nonnative organisms.

\subsection{THE APPLICATION OF DECISION-MAKING METHODS}

General approaches to making decisions about introducing non-native species have been classified as "Judgement", "Precedent", and "Formal Analysis" (U.S. Congress 1993). Decisions by "Judgement" may be characterized by relatively undefined procedures and, frequently, little or no documentation. Decisions by "Precedent" follow earlier decisions and are usually documented. Decisions by "Formal Analysis" follow well-defined procedures and are clearly documented.

\subsection{Formal Analysis:}

Trends in the Canada and the U.S. are toward formal analysis which can include risk analysis, environmental assessment, and/or economic analysis. A review of formal analysis methods made the following points (U.S. Congress 1993):

Risk Analysis: Quantitative predictions of the impact of non-native introductions cannot be made with high degrees of confidence. Useful qualitative predictions often can be made. Expert judgement based on research and diverse input is the most broadly feasible approach. Experimentation reduces uncertainty but requires resources. Application of risk analysis to the importation of larch timber from Siberia to the West Coast found serious risks posed by several pests.

Environmental Impact Assessment: In the U.S., the assessment of environmental impacts is a legally mandated process that follows a standardized check list leading to an initial decision of whether a detailed assessment is required. Precise methods for assessment are not imposed but standards are provided. This approach is usually less quantitative than risk analysis. As of 1993, however, environmental impact assessments were not required and were not used in deciding whether to allow the introduction of non-native plants.

Economic Analysis: The typical uncertainty of projections for biological and economic effects for the future limit the usefulness of economic analysis in decision making on nonnative plants. In addition, economic projections are considered to account poorly for cases where future effects have a low probability of occurring yet will have a high impact if they do. Nevertheless, the rigorous structure of economic analysis can be useful in forcing decision makers to consider all relevant factors.

For Canada, a "Safety-based model for the regulation of forest trees" has been proposed (Anon. 1999a). This model is a sequence of questions leading to a judgement that 
introduction of a specific tree or trees engenders acceptable or unacceptable risk. Invasiveness, gene contamination, pest risks, and impacts on non-target organisms and biodiversity are included as items requiring assessment. Where proposed introductions cannot be considered to be "familiar" and "substantially equivalent" in terms of safety, a formal testing protocol has been proposed. The protocol includes different levels of containment as a part of risk assessment. These levels progress from "contained" to "confined field trials", to "unconfined release" prior to commercialization. It is at the stage of commercialization that Provincial regulations are proposed to become operative.

\subsection{Protocols:}

Protocols are written codes to guide a prescribed course of action. Some have been proposed to assist decision making on the introduction of non-native species but seem to remain voluntary and not commonly adopted. An outline of steps for a benefit/cost protocol is available in U.S. Congress (1993). A summary of the more general Position Statement by the International Union for Conservation of Nature and Natural Resources focuses more on principles (Anon. 1987). The provisions include:

$>$ Release of a non-indigenous species should be considered only if clear and welldefined benefits to humans or natural communities can be foreseen.

$>$ Releases should be considered only if no indigenous species is suitable.

$>$ No non-indigenous species should be deliberately released into any natural area; releases into semi-natural areas should not occur absent exceptional reasons.

$>$ Planned releases, including those for biological control, entail three critical phases: rigorous assessment of desirability; controlled experimental release; and extensive release accompanied by careful monitoring and pre-arrangement for control and eradication measures, if necessary.

$>$ Special consideration should be given to eradicating existing introductions in ecologically vulnerable areas."

\subsection{CONCLUSIONS}

From this review of general issues around reforestation with non-native trees and consideration of reforestation in Alberta, we offer the following conclusions:

1. The existing policy of exclusion for non-native trees in reforestation of public lands has served Alberta well. It has prevented the casual introduction of species that could result in plantation failure as well as genetic and pest problems for surrounding native forests.

2. Despite the usefulness of an exclusionary policy, highly successful use of non-native trees for reforestation elsewhere suggests that a protocol in which benefits and risks are carefully weighed might offer opportunities for enhancement of Alberta's forest resources. 
A protocol for the use of non-native trees in reforestation might include the following elements:

a. formal standards to be met before reforestation with non-native trees would be allowed on public land. Standards might include requirements for testing based on available experience and expected risk. One outline for a decision-making protocol is in Table 1.

b. policies applicable to seed and vegetative materials, as well as deployment. Issues of genetic diversity and self-sustainability, for example, would need to be addressed.

c. a formal plan for monitoring plantation development. Particular emphasis would be on pests and the potential for development of pest epicentres.

d. assignment of liability for negative ecosystem impacts arising from such reforestation. If reforestation with non-native trees results in lowered productivity of public lands, the responsibility for remediation would be specified before reforestation begins. Lowered productivity would include reduced production of non-native tree plantations as well as negative impacts on native forests. In the latter case, responsibility for problems of invasiveness, genetic contamination or pests attributable to non-native tree plantations could extend to public lands beyond the borders of non-native tree plantations. 
Table 1. A preliminary protocol for approval or rejection of requests for the operational planting of non-native trees.

\section{Anticipated Effects}

\section{Sequential Questions}

1. What is the potential economic impact on quality and/or quantity of forest products?

2. What are the expected risks* to non-native trees from native pests of Alberta? Will non-native forests be especially susceptible to native pests?

3. What are the expected risks to native forests from pests of the non-native habitats? Will native forests be especially susceptible to pests that could enter with non-native trees?

4. What is the expected risk from gene contamination? Will trees from non-native forests cross with native trees and change the genetic composition of native forests?

5. What is the expected risk of invasiveness? Can non-native trees reproduce and become established in sufficient numbers to expand the boundaries of plantations and interfere with native forest?

6. What is the expected risk of negative impacts on soil? Changes might include acidity, nutrient cycling, organic matter and soil organisms.

7. What is the expected risk of negative impacts on wildlife? Changes might include nesting opportunities for birds, cover and food for animals, etc.

8. What are longer-term risks to ecological processes and to forest sustainability?
Large

Go to 2 .

Reject

Explore pest Go to 4 . inspection options. If favorable, go to 4 ., if not reject

Reject

Reject

Reject
Reject

Reject

Reject
Small

Go to 3 . Go to 3 .

Reject
Unknown

Estimate from research and address question 3. again

Go to 5. Estimate from research and address question 4. again

Go to $6 . \quad$ Go to 6 .
Go to 6.

Estimate from research and address question 6. again

$\begin{array}{ll}\text { Accept } & \text { Accept } \\ \text { with } & \text { with } \\ \text { specified } & \text { specified } \\ \text { testing and } & \text { testing and } \\ \text { monitoring } & \text { monitoring } \\ \text { Accept } & \text { Accept with } \\ \text { with } & \text { specified testing } \\ \text { specified } & \text { and monitoring } \\ \text { testing and } & \\ \text { monitoring } & \end{array}$

* Expected risk is a combination of probability of occurrence and impact if the risk is realized. For all risks, proposed practices to reduce risk may improve the prospects for approval. 
13.0 REFERENCES(Not all references are cited in the text; many contribute to the lists of pests in Appendix III)

Alfaro, R.I., G. Kiss and R.G. Fraser. 1994. The white pine weevil: biology, damage and management. Proc. Of Symp. at Richmond, B.C., Jan. 19-21, 1994. Canada-British Columbia Partnership Agreement on Forest Resources Development. FRDA II. Can. For. Serv. , Pacific For. Cent. and B.C. Min. For., Victoria. FRDA Rep. 226: 311 pp.

Allen, E. D. Morrison and G. Wallis. 1996. Common tree diseases of British Columbia. Nat. Resources Can., Can. For. Serv., Victoria, B.C. 178 pp.

Annila, E., K. Heliovaara, K. Puukko and M. Roussi. 1983. Pests of lodgepole pine in Finland. Communicationses Instituti For. Fenniae 115: 1-22.

Anon. Undated (possibly early 1970's). Exotics in forest practice in Alberta. Unpublished manuscript. AB Forest Service. $6 \mathrm{pp}$.

Anon. 1965. Plant hardiness zone map. U.S. Dept. Agr. Misc. Pub. 814. 1 p.

Anon. 1987. The IUCN position statement on translocation of living organisms. Cited from U.S. Congress, 1993.

Anon. 1995. Seed and vegetative material guidebook. B.C. Min. For., Victoria.

Anon. 1999a. Regulatory proposal: Assessment criteria for determining environmental safety of forest trees with novel traits. Draft Manuscript. $26 \mathrm{pp}$.

Anon. 1999b. Establishment to free growing guidebook (Draft 3). B.C. Min. For., Victoria.

Anon. 2000. Alberta regeneration survey manual. Alberta Environment, Edmonton. 56 pp.

Armstrong, J.A. and W.G.H. Ives. (Ed.) Forest insect pests in Canada. Nat. Resources Can., Can. For. Serv. Ottawa. 732 pp.

Basham, J.T. 1958. Decay in trembling aspen. Can. J. Bot. 36: 491-505.

Biodiversity Working Group. 1995. Canadian biodiversity strategy. Canada's reponse to the Convention on Biological Diversity. Canadian Museum of nature. 80 pp.

Bloomberg, W.J. 1962. Cytospora canker of poplars: factors influencing the development of the disease. Can. J. Bot. 40: 1271-1280.

Bongarten, B. C., and J.W. Hanover. 1982. Hybridization between white, red, blue, and white X blue spruces. For. Sci. 28: 129-134.

Braatne, J.H., S.R. Rood and P.E. Heilman. 1996. Life history, ecology, and conservation of riparian cottonwoods in North America In Stettler, R.F., H.D. Bradshaw, Jr., P.E. Heilman and T.M. Hinckley. 1996. Biology of Populus and its implications for management and conservation. NRC Research Press, Ottawa. pp 57-85. 
Brandt, J.P., H.F. Cerezke, K.I. Mallett, W.J.A. Volney and J.W. Weber. Factors affecting trembling aspen (Populus tremuloides Michx.) in the Boreal Forest of west-central Canada. Unpublished manuscript.

Brasier, C. 2000.The rise of hybrid fungi. Nature 405: 134-135.

Butin, H. 1995. Three diseases and disorders: causes, biology and control in forest and amenity trees. Biologische Bundesanstalt fur Land- und Firstwirtschaft Institut fur Pflanzenschutz im Forst, Braunschweig, Germany. Translation by R. Strouts; D. Lonsdale, Ed. Oxford Univ. Press. 252 pp.

Cain, S.A. 1971. Foundations of plant geography. Hafner Pub. Co., New York . 556 pp.

Canadian Council of Forest Ministers. 1995. Defining sustainable forest management - A Canadian approach to criteria and indicators. Can. For. Serv., Nat. Res. Can. 22 pp.

Callan, B.E. 1998. Diseases of Populus in British Columbia: a diagnostic manual. Nat. Resources Can., Can. For Serv., Victoria, B.C. 157 pp.

Cerezke, H.F. 1994. Warren root collar weevil, Hylobius warreni Wood (Coleoptera:

Curculionidae), in Canada: ecology, behavior, damage relationships, and management. Can. Entomol. 126: 1383-1442.

Cerezke, H.F. and B.A. Pendrel. 1995. Root collar weevils, Hylobius and Steremnius spp. Chap. 28, pp 253-263. In Forest insect pests in Canada, J.A. Armstrong and W.G.H. Ives, editors. Nat. Resources Canada, Can. For. Serv., Ottawa.

Charleson, L. 1999. Report 1996-1999. Western Boreal Aspen Cooperative. 22 pp.

Coates, K.D., S. Haeussler, S. Lindeburgh, R. Pojar, and A.J. Stock. 1994. Ecology and silviculture of Interior spruce in British Columbia. Canada-British Columbia Partnership Agreement on Forest Resource Development: FRDA II. Can. For. Serv., Pacific For. Cent./B.C. Min. of Forests, Res. Br. 182 pp.

Copony, J.A. and B.V. Barnes. 1974.Clonal variation in the incidence of Hypoxylon canker on trembling aspen. Can. J. Bot. 52: 1475.

Corn, M.L, E.H. Buck, J. Rawson and E. Fischer. 1999. Harmful non-native species: Issues for Congress. Comm. for the National Inst. for the Environ. Washington, D.C.

DeByle, N.V. and R.P. Winokur, editors. 1985. Aspen: ecology and management in the western United States. U.S.D.A.,For. Serv., Rocky Mt. For. and Range Expt. Stn., Ft. Collins, Colorado. Gen. Tech. Rep. RM-119: 283 pp.

Dickmann, D.I. and K.W. Stuart. 1983. The culture of poplars. Dept. of Forestry, Michigan State Univ., East Lansing. 155 pp. 
DiFazio, S.P., S. Leonardi, S. Cheng and S.H. Strauss. 1999. Assessing potential risks of transgene escape from fiber plantations. hhtp://www.fsl.orst.edu/tgerc/genfor 2 .htm. 6 pp. Duffield, J.W. 1953. Relationships and species hybridization in the genus Pinus. Zeit. Forstgenetik und Forstpflanzuch. 1: 93-97.

Eckenwalder, J.E. 1996. Systematics and evolution of Populus. In Stettler, R.F., H.D. Bradshaw, Jr., P.E. Heilman and T.M. Hinckley. 1996. Biology of Populus and its implications for management and conservation. NRC Research Press, Ottawa. pp 7-30.

Ernst, S.G., J.W. Hanover and D.E. Keathley. 1990. Assessment of natural interspecific hybridization of blue and Engelmann spruce in southwestern Colorado. Can. Jour. Bot. 68: 1489-1496.

French, J.R. and J.H. Hart. 1978. Variation in resistance of trembling aspen to Hypoxylon mammatum identified by inoculating naturally occurring clones. Phytopath. 68: 485-489.

Furniss, R.L., and V.M. Carolin. 1977. Western forest insects. U.S.D.A., For. Serv., Washington, D.C. Misc. Publ. No. 1339: 654 pp.

Gerhold, H.D., E.J. Schreiner, R.E. McDermott, and J.A. Winieski, editors. 1966. Breeding pestresistant trees. Proc. N.A.T.O. and N.S.F. Advanced Study Inst. on Genetic Improvement for Disease and Insect Resistance of Forest Trees, Penn. State Univ., Aug. 30 - Sept. 11, 1964. Pergamon Press, New York: 505 pp.

Goheen, D.J., and B.M. Tkacz. 1995. Pest risks associated with importation of unprocessed larch logs from Siberia and the Russian far east to the United States, pp 162- 165. In: Ecology and management of Larix forests: a look ahead. W.C Schmidt and K.J. McDonald, compilers. 1995. Proc. of Intern'1 Symp. at Whitefish, Montana, Oct. 5-9, 1992. U.S.D.A., For. Serv., Intermountain Res. Stn., Ogden, Utah. Gen. Tech. Rep. GTR-INT-319.

Hagle, S.K., S. Tunnock, K.E. Gibson, and C.J. Gilligan. 1987. Field guide to diseases and insect pests of Idaho and Montana forests. U.S.D.A., For. Serv., Missoula, Montana. 123 pp.

Halmschlager, E., A. Gabler and F. Andrae. 2000. The impact of Sirococcus shoot blight on radialand height growth of Norway spruce (Picea abies) in young plantations. For. Path. 30: 127-133.

Hanover, J.W. 1975. Genetics of blue spruce. U.S.D.A. For. Serv. Res. Pap. WO-28. 12 pp.

Hansson, P. 1998. Susceptibility of different provenances of Pinus sylvestris, Pinus contorta and Picea abies to Gremmeniella abietina. Eur. J. For. Path. 28: 21-32.

Hepting, G.H. 1971. Diseases of forest and shade trees of the United States. U.S.D.A., For. Serv., Washington, D.C. Agriculture Handbook No. 386. 658 pp.

Heybroek, H.M., B.R. Stephan, and K. von Weissenberg, editors. 1982. Resistance to diseases and pests in forest trees. Proc. Third Intern'l Workshop on the genetics of host-parasite interactions in forestry. Wageningen, the Netherlands, 14-21 Sept., 1980. Centre for Agric. Publ. and Documents., Wageningen. 
Hiratsuka, Y., D.W. Langor, and P.E. Crane. 1995. A field guide to forest insects and diseases of the prairie provinces. Nat. Resources Can., Can. For. Serv., Edmonton, Alta. Special Report 3; $297 \mathrm{pp}$.

Hiratsuka, Y. and A.A. Loman. 1984. Decay of aspen and balsam poplar in Alberta. Can. For. Serv., North. For. Res. Cent., Edmonton. Inf. Rep. NOR-X-262: 19 pp.

Hsiang, T., G.A. Chastagner, J.M. Dunlap, and R.F. Stettler. 1993. Genetic variation and productivity of Populus trichocarpa and its hybrids. VI. Field susceptibility of seedlings to Melampsora occidentalis leaf rust. Can. J. For. Res. 23: 436-441.

Hyun, S.K. 1976. Interspecific hybridization in pines with special reference to $P$. rigida $\mathrm{X}$ taeda. Silvae Gen. 25:188-191.

Ives, W.G.H., and H.R. Wong. 1988. Tree and shrub insects of the prairie provinces. Can. For. Serv., North. For. Cent, Edmonton, Alberta. Inf. Rep. NOR-X-292:

Jalkanen, R., T. Aalto, and M-L Lahti, editors. 1993. Forest pathological research in northern forests with special reference to abiotic stress factors. The Finnish Forest Research Institute, Dept. of For. Ecology, Rovaniemi, Finland. Res. Papers 451. 170 pp.

Kaitera, J. 2000. Analysis of Cronartium flaccidium lesion development on pole-size Scots pine. Silva Fennica 34: 21-27.

Kowarik, I. 1995. Time lags in biological invasions with regard to success and failure of alien species. In Plant invasions - general aspects and special problems. Ed. by Pysek, P., K. Prach, M. Rejmanek and M. Wade. SPB Academic Publishing, Amsterdam. pp 15-38

Laflamme, G., J.A. Berube, and R.C. Hamelin, editors. 1998. Foliage, shoot and stem diseases of trees. Proc. of the IUFRO WP 7.02.02 Meeting in Quebec City, May 25-31, 1997. Nat. Resources Can., Can. For. Serv., Laurentian For. Cent., Sainte-Foy, Quebec. Inf. Rep. LAU-X122. $272 \mathrm{pp}$.

Lanner, R.M. 1966. Needed: a new approach to the study of pollen dispersal. Silvae Gen. 15:5052.

Liebhold, A.M., W.L. MacDonald, D. Bergdahl, and V.C. Mastro. 1995. Invasion by exotic forest pests: A threat to forest ecosystems. Soc. Am. For., For. Sci. Monog. 30: 49 pp.

Little, E.L., Jr. 1979. Check list of United States trees. U.S.D.A. For. Serv. Ag. Handbook 541. $375 \mathrm{pp}$.

Lonsdale, D., and J. Rose. 1998. Resistance of new Belgium poplar clones to British isolates of the bacterial canker pathogens, Xanthomonas populi. Eur. J. For. Path. 28: 227-232.

Lundmark, J.E., B. Berg and A. Nilsson. 1982. The influence of Pinus contorta on the soil and ground vegetation in comparison with Pinus sylvestris. Sveriges Skogsv. Forb. Tidskrift 80 :43-48. Original not seen; cited from Zobel, et al. 1987. 
Mallett, K.I. 1992. Armillaria root rot in the Canadian prairie provinces. For. Can., Northwest Reg., North. For. Cent., Edmonton, Alberta. Inf. Rep. NOR-X-329.

Martineau, R. 1984. Insects harmful to forest trees. Multiscience Publications Ltd., Montreal, Quebec. $261 \mathrm{pp}$.

Morrison, D.J., H. Merler, and D. Norris. 1992. Detection, recognition, and the management of Armillaria and Phellinus root diseases in southern Interior of British Columbia. For. Can., Can. For. Serv. and British Columbia Ministry of Forests, Victoria, B.C. FRDA Report 179.

Myren, D.T. (editor); G. Laflamme, P. Singh, L.P. Magasi, D. Lachance (assoc. editors). 1994. Tree diseases of eastern Canada. Nat. Resources Can., Can. For. Serv., Ottawa. 159 pp.

Native Plant Working Group. 1999. Draft native plant revegetation guidelines for Alberta. Ed by H.S. Gerling. Alberta Agr., Food and Rural Dev. Edmonton. 55 pp.

Newcombe, G. 1996. The specificity of fungal pathogens of Populus. In Biology of Populus and its implications for management and conservation. Part I, Chapter 10. Edited by R.F.Stettler, H.D. Bradshaw, Jr., P.E. Heilman, and T.M. Hinckley. NRC Res. Press, National Res. Council of Canada, Ottawa. pp. 223-246.

Newcombe, G. 1998. A review of exapted resistance to diseases of Populus. Eur. J. For. Path. 28: 209-216.

Newcombe, G.; B. Stirling; S. McDonald; and H.D. Bradshaw, Jr. 2000. Melampsora x columbiana a natural hybrid of M. medusa and M. occidentalis. Mycol. Res. 104: 261-274.

Niemela, P., and W.J. Mattson. 1992. Introduced phytophagus insects in North American forests: Why so many? In American forestry - an evolving tradition. Proc. 1992 Nat. Conv. Soc Am. For., Bethesda, MD. P. 202-208.

Nuttonson, M.Y. 1950. Agricultural climatology of Siberia, natural belts, and agro-climatic analogues in North America. Am. Inst. Of Crop Ecology. Washington, D.C. 57 pp.

Oil Sands reclamation Committee. 1998. Guidelines for reclamation to forest vegetation in the Athabasca Oil Sands Region. ISBN 0-7785-0411-5. 59 pp.

Ostry, M.E. and F.L. Henderson. 1990. Populus: a bibliography of world literature. 1975-1988. U.S.D.A., For. Serv., North Central For. Expt. Stn., St. Paul, Minnesota. Gen. Tech. Rep. No. 104: $721 \mathrm{pp}$.

Ostry, M.E., L.F. Wilson, H.S. McNabb, Jr., and L.M. Moore. 1989. A guide to insect, disease, pests of poplars. U.S.D.A., For. Serv., Washington, D.C. Agric. Handbook 677; 118 pp.

Perala, D.A. 1984. How endemic injuries affect early growth of aspen suckers. Can. J. For. Res. 14: 755-762.

Peterson, E.B. and N.M. Peterson. 1992. Ecology, management, and use of aspen and balsam poplar in the prairie provinces. For. Can., North. For. Cent, Edmonton Special Rep. 1: 252 pp. 
Peterson, G.W., and R.S. Smith, Jr., tech. coordinators. 1975. Forest nursery diseases in the United States. U.S.D.A., For. Serv., Washington, D.C. Agric. Handbook No. 470; 125 pp.

Pinon, J. 1992. Variability in the genus Populus in sensitivity to Melampsora rusts. Silvae Genet. 41: 25-34.

Piri, T. 2000. Response of compensatory-fertilized Pinus sylvestris to infection by Heterobasidion annosum. Scand. J. For. Res. 15: 218-224.

Ranta, H., P. Pulkkinen, and S. Neuvonen. 2000. Susceptibility of six Scots pine clones to the pathogenic fungus Gremmeniella abietina. Scand. J. For. Res. 15: 7-12.

Reichard, S.H., and C.W. Hamilton. 1997. Predicting invasions of woody plants introduced into North America. Conservation Biology 11:193-203.

Rehfeldt, G.E., C.C. Ying, D.L. Spittlehouse, and D.A. Hamilton. 1999a. Genetic responses to climate in Pinus contorta in British Columbia: niche breadth, climate change and reforestation. Ecol. Monogr. 69: 375-407

Rehfeldt, G.E., N.M. Tchebakova, and L.K. Barnhardt. 1999b. Efficacy of climate transfer function: Introduction of Eurasian populations of Larix into Alberta. Can. J. For. Res. 29: $1660-1668$.

Rejmanek, M, and D.M. Richardson. 1996. What attributes make some plant species more invasive. Ecology 77:1655-1661.

Richardson, D.M. 1998. Forestry trees as invasive aliens. Conservation Biology 12: 16-26. Ronald, W.G. 1982. Intersectional hybridization of Populus sections Leuce-Aigeros and Leuce-Tacamahaca. Silvae Gen.: 94-99.

Ronnberg, J., and B.B. Jorgensen. 2000. Incidence of root and butt rot in consecutive rotations of Picea abies. Scan. J. For. Res. 15: 210-217.

Rose, A.H. and O.H. Lindquist. 1973. Insects of eastern pines. Environ. Can., Can. For. Serv.,Sault Ste. Marie, Ont. Publ. 1313F; 127 pp.

Rose, A.H., and O.H. Lindquist. 1980. Insects of eastern larch, cedar and juniper. Can. Dept. Environ., Can. For. Serv., Ottawa. For. Tech. Rep. 28; 99 pp.

Rozhkov, A.S., editor. 1966. Pests of Siberian larch. Academy of Sciences of the U.S.S.R.Siberian Dept., East-Siberia Biological Institute. 1966. Translation by Israel Program for Scientific Translations, Jerusalem, 1970. Published pursuant to Agreement with U.S.D.A. and the National Science Foundation, Washington, D.C. 393 pp.

Sarvas, R. 1955. Ein beitrag zur fernverbreitung des blutenstaubes einiger waldbaume. Silvae Gen. 4: $137-142$. 
Schmidt, W.C. and K. J. McDonald, compilers. 1995. Ecology and management of Larix forests: a look ahead. Proc. Internat'l Symp., Oct. 5-9, 1992, Whitefish, Montana. U.S.D.A., For. Serv., Intermountain Res. Stn., Ogden, Utah. Gen. Tech. Rep. GTR-INT-319: 521 pp.

Soos, J. and B.N.Brown. 1970. Performance of some native and exotic pines in central Alberta.Can. For. Serv., For. Res. Lab., Edmonton. Info. Rept. A-X-28: 21 pp.

Shaw, C.G. and G.A. Kile. 1991. Armillaria root disease. U.S.D.A., For. Serv., Washington, D.C. Agric. Handbook No. 691: 233 pp.

Spiers, A. G. 1983. Host range and pathogenicity studies of Marssonina brunnea to poplars. Eur. J. For. Path. 13: 181-196.

Spiers, A.G. 1998. Melampsora and Marssonina pathogens of poplars and willows in New Zealand. Eur. J. For. Path. 28: 233-240.

Stettler, R.F., H.D. Bradshaw, Jr., P.E. Heilman, and T.M. Hinckley. 1996. Biology of Populus and its implications for management and conservation. NRC Research Press, Ottawa, Ontario. $539 \mathrm{pp}$.

Thomas, B. 1998. Tree improvement program - where we've been. Research Manual, AlbertaPacific Forest Industries. 123 pp.

Thomas, G.P., D.E. Etheridge, and G. Paul. 1960. Fungi and decay in aspen and balsam poplar in the boreal forest region, Alberta. Can. J. Bot. 38: 459-466

Thomas, J.B. 1978. A review of the economic impact of insects on the genus Populus in Ontario. Can. For. Serv., Sault Ste. Marie, Ontario. Rep. O-X-271: 45 pp.

U.S. Congress. 1993. Harmful non-indigenous species in the United States. Office of TechnologyAssessment, OTA-F-565. Washington, DC. 391 pp.

van Oosten, C. 2000. Activities related to poplar and willow cultivation and utilization in Canada1996-1999. Poplar Council of Canada, Edmonton. 49 pp.

von Segebaden, G. 1993. Lodgepole pine in Sweden - A situation report. In Pinus contorta - from untamed forest to domesticated crop, Ed. by Lindgren, D. Swedish Univ. for Agr. Sci., Dept. of Forest Genetics and Plant Physiology Report 11: 8-23.

Wall, R.E. 1969. Distribution of Fomes igniarius in aspen stands as affected by clonal variation. Can. For. Serv., Bi-Mon. Res. Notes 25: 5.

Wall, R.E. 1971. Variation in decay in aspen stands as affected by their clonal growth pattern. Can. J. For. Res. 1: 141-146.

Whitham, T.G. 1989. Plant hybrid zones as sinks for pests. Science 244: 1490-1493. 
Whitham, T.G., K.D. Floate, G.D. Martinsen, E.M. Driebe, and P. Keim. 1996. Ecological and evolutionary implications of hybridization: Populus-herbivore interactions. In Biology of Populus and its implications for management and conservation. Part I, Chapter 11. Edited by R.F. Stettler, H.D. Bradshaw, Jr., P.E. Heilman, and T.M. Hinckley. NRC Research Press, National Res. Council, Ottawa. pp 247-275.

Witzell, J. and M. Karlmann. 2000. Importance of site type and tree species on disease incidence of Gremmeniella abietina in areas with a harsh climate in northern Sweden. Scan. J. For. Res. 15: 202-209.

Wright, J.W. 1955. Species crossability in spruce in relation to distribution and taxonomy. For. Sci. 1:319-349.

----. 1962. Species and racial hybridization. In Genetics of forest tree improvement. FAO Forestry and Forest Products Studies No. 16. Food and Agr. Org. of the United Nations, Rome. pp 159227.

----. 1976. Species and racial hybridization. In Introduction to forest genetics. Academic Press, New York. Pp 313 to 342.

Zobel, B.J. 1982. The world's need for pest -resistant forest trees, pp. 1-8. In: Resistance to diseases and pests in forest trees. 1982. H.M. Heybroek, B.R. Stephan and K. von Weissenberg, editors. Proc. of $3^{\text {rd }}$. Intern'l Workshop on the genetics of host-parasite intractions in forestry, Wagenigen, the Netherlands, 14-21 Sept., 1980.

Zobel, B.J. and J.T.Talbert. 1984. Applied Forest Tree Improvement. Wiley and Sons, Toronto. $505 \mathrm{pp}$.

Zobel, B.J., van Wyk, G. and Stahl, P. 1987. Growing exotic forests. Wiley and Sons, Toronto. $485 \mathrm{pp}$. 


\subsection{ACKNOWLEDGEMENTS}

Preparation of this report was requested and guided by a committee comprised of Harry Archibald, Narinder Dhir, Steven Ferdinand and Hideji Ono. Herbert Cerezke and Donald Lester participated in discussions with the Committee.

The following persons contributed references, experience and/or opinions for the development of this report.

\begin{tabular}{|c|c|c|c|}
\hline Alberta Environment & $\begin{array}{c}\text { BC Ministry of } \\
\text { Forests }\end{array}$ & Forestry Canada & Fort James Corp. \\
\hline - Leonard Barnhardt & - Barry Jaquish & - Judy Loo & - Brian Stanton \\
\hline - Heather Sinton & - Leslie McAuley & & \\
\hline - Mica Wickramasekara & - John McClarnon & & \\
\hline - Evelynne Wrangler & - Ralph Winter & & \\
\hline & - Alvin Yanchuk & & \\
\hline 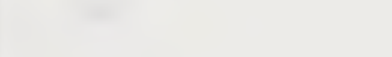 & - Cheng Ying & & \\
\hline J. D. Irving Ltd. & $\begin{array}{l}\text { Quebec Ministry of } \\
\text { Natural Resources }\end{array}$ & $\begin{array}{c}\text { New Brunswick } \\
\text { Department of } \\
\text { Natural Resources } \\
\end{array}$ & $\begin{array}{l}\text { Ontario Ministry of } \\
\text { Natural Resources } \\
\end{array}$ \\
\hline - Greg Adams & - Michel Villeneuve & - Kathy Tosh & Dennis Joyce \\
\hline U.S. Forest Service & $\begin{array}{l}\text { University of } \\
\text { Washington }\end{array}$ & & \\
\hline - Gerald Rehfeldt & - Richard Stettler & & \\
\hline
\end{tabular}




\section{APPENDIX I}

Decision-making chart: sourcing native plant material (redrawn from Native Plant Working Group 1999)

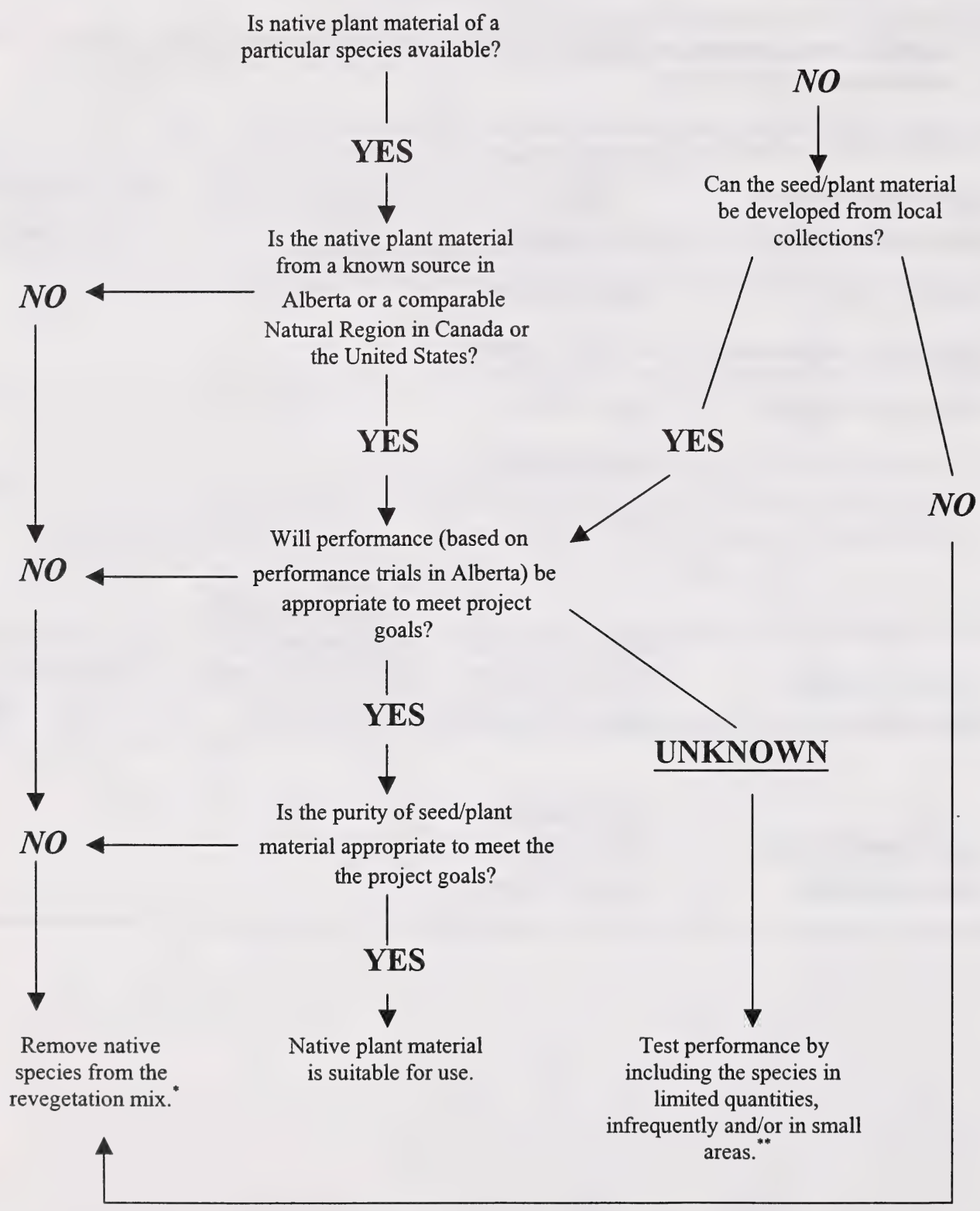

prior to removing species from the revegetation mix, multiple attempts to secure alternative sources is recommended.

** records of procedures and results should be maintained and made generally available. 


\section{APPENDIX II}

Non-native forest tree species of current interest in Alberta and the extent of testing to date.

\section{Genetic Sampling}

Siberian larch

Blue spruce

Norway spruce

White X Engelmann Spruce

Red Pine

Scots pine

Aspens and hybrids ${ }^{\mathrm{a}, \mathrm{b}}$

Cottonwoods and hybrids ${ }^{b}$
- Limited provenance and progeny testing, good seed sources identified, species testing of unknown origins

- Unknown

- Unknown

- A few progenies from the B.C. program

- Eight seedlots, 6 of known origin

- Three seedlots of uncertain origin

P. tremuloides - Several hundred selected trees including many not acceptable for public lands using current policy.

Interspecific

hybrids with

P. tremuloides - Several dozen

P. alba

- Few

$P$. davidiana - Several dozen

P. tremula

- ?

Interspecific

hybrids with

alba, tremula,

davidiana - A few dozen

P. balsamifera- Several dozen

Interspecific

Hybrids with

P. balsamifera- Several dozen

P. deltoides - Several dozen

Interspecific

Hybrids with

P. deltoides - Several hundred 
P. trichocarpa - None

Interspecific

hybrids with

$P$. trichocarpa - Mostly with $P$. deltoides, several dozen with P. nigra

P. nigra - One

Interspecific

Hybrids with

P. nigra - Mostly with $P$. trichocarpa, also with several other species

Other species - A few clones include crosses with several other species

\section{Environmental Sampling \\ (not including amenity plantings)}

Siberian larch

Blue spruce

Norway spruce

White X Engelmann spruce

Red pine

Scots pine

Aspens and hybrids ${ }^{\mathrm{B}, \mathrm{C}}$

Cottonwoods and hybrids ${ }^{\mathrm{C}}$
At 12 or more locations

At 5 locations

At 5 locations

At 3 locations

At 2 locations

At 5 locations

Mostly at 1 or 2 locations

Mostly at 1 location

\section{Duration of Testing}

10 to 40 years

$30+$ years $^{\mathrm{A}}$

$30+$ years $^{\mathrm{A}}$

1 year

18 years

$30+$ years $^{\mathrm{A}}$

From 1 to 4 years

From 1 to 7 years

\footnotetext{
A - Last reported on in 1969 ?

B - Charleson, L. 1999

C - Thomas, B. 1998
} 
Pests of concern for non-native forest tree species of current interest in Alberta.

(For non-native pests, ${ }^{*}$ indicates that the pest is present in Canada but not known to be present in Alberta; ** indicates that the pest is known to be present in Alberta.)

\section{SIBERIAN LARCH}

\section{Native Pests}

\section{Major pests:}

Pristiphora erichsonnii - larch sawfly

Armillaria ostoyae - Armillaria root rot

Lepus americanus- snowshoe hare

\section{Lesser pests:}

Dendroctonus simplex - larch beetle

Dioryctria abietivorella - fir coneworm

Monochamus scutellatus - whitespotted sawyer beetle

Damping off disease (several fungal spp.)

Inonotus tomentosus - tomentosus root and butt rot

Melampsora albertensis and $M$. occidentalis - larch is an alternate host for these

leaf rusts on poplars

Phaeolus schweinitzii - velvet top fungus causing brown cubical rot

Phellinus pini-red ring rot fungus causing white trunk pocket rot

Erethizon dorsatum - porcupine

\section{Non-native Pests}

\section{Major pests:}

Dendrolimus superans sibericus - a defoliating insect

Lymantria dispar - Asian gypsy moth

Lymantria monaca - nun moth, a defoliating insect

Zeiraphera diniana - larch bud moth

*Heterobasidion annosum - Annosus root and butt rot

*Lachnellula willkommii - larch canker disease

\section{Lesser pests:}

Dasyneura laricis - a bud midge

Ips subelongatus - a bark beetle

Ips typographus - spruce bark beetle

Monochamus sutor - a wood boring sawyer beetle

Pristiphora laricis - a defoliator sawfly

Strobilomyia laricis - a seed and cone maggot

*Hyperdermella laricis - a needle fungus disease

Mycosphaerella laricina - larch needle cast

Phacidium coniferum -- a canker disease 


\section{BLUE SPRUCE}

\section{Native Pests}

Major pests:

Choristoneura fumiferana - spruce budworm

Pikonema alaskensis - yellowheaded spruce sawfly

Pissodes strobi - white pine weevil

Armillaria ostoyae - Armillara root rot

Lepus americanus - snowshoe hare

\section{Lesser pests:}

Dioryctria abietivorella - fir coneworm

Monochamus scutellatus - whitespotted sawyer beetle

Strobilomyia neanthracina - spruce cone maggot

Zeiraphera canadensis - spruce bud moth

Chrysomyxa ledicola - spruce needle rust

Chrysomyxa pirolata - spruce cone rust

Inonotus tomentosus - tomentosus root and butt rot

Phaeolus schweinitzii - velvet top fungus causing brown cubical rot

Phellinus pini - red ring rot

Erethizon dorsatum - porcupine

\section{Non-native Pests}

\section{Lesser pests:}

Choristoneura occidentalis - western spruce budworm

Damping off disease (several fungal spp.)

Gemmamyces piceae - cucurbitaria bud blight

* Gremmeniella abietina - North American race of scleroderris canker disease

*Heterobasidion annosum - annosus root and butt rot

*Leucostoma kunzei - a canker disease

\section{NORWAY SPRUCE}

\section{Native Pests}

Major pests:

Choristoneura fumiferana - spruce budworm

Pikonema alaskensis - yellowheaded spruce sawfly

Pissodes strobi - white pine weevil

Armillaria ostoyae - Armillaria root rot

Inonotus tomentosus - tomentosus root and butt rot

Lepus americanus - snowshoe hare

\section{Lesser pests:}

Cydia strobilella - spruce seed moth

Dioryctria abietivorella - fir coneworm

Dioryctria reniculelloides - spruce coneworm

Monochamus scutellatus - whitespotted sawyer beetle

Strobilomyia neanthracina - spruce cone maggot

Chrysomyxa ledicola - spruce needle rust 
Chrysomyxa pirolata - spruce cone rust

Damping off disease (several fungal spp.)

Phaeolus schweinitzii - velvet top fungus causing brown cubical rot

Phellinus pini - red ring rot

Sirococcus strobilinum - sirococcus shoot dieback

Stereum sanguinolentum - a stem decaying fungus

\section{Non-native Pests}

Major pests:

Hylobius abietis - large pine weevil

* Gremmeniella abietina - scleroderris canker disease

*Heterobasidion annosum - annosus root and butt rot

* Sirococcus congenus - sirococcus shoot blight

\section{Lesser pests:}

Ips typographus - spruce bark beetle

Chrysomyxa abietis - a spruce needle rust

Chrysomyxa pyrolatum - a spruce cone rust

Fomitopsis pinicola - red belt fungus (a brown rot fungus)

Gemmamyces piceae - cucurbitaria bud blight

Lophodermium piceae - a needle cast disease

Nectria fuckeliana - spruce bark disease

\section{WHITE X ENGELMANN SPRUCE}

\section{Native Pests}

\section{Major pests:}

Choristoneura fumiferana - spruce budworm

Pikonema alaskensis - yellowheaded spruce sawfly

Pissodes strobi - white pine weevil

Armillaria ostoyae - Armillaria root rot

Inonotus tomentosus - tomentosus root and butt rot

Lepus americanus - snowshoe hare

\section{Lesser pests:}

Dioryctria abietivorella - fir coneworm

Monochamus scutellatus - whitespotted sawyer beetle

Strobilomyia neanthracina - spruce cone maggot

Chrysomyxa ledicola - spruce needle rust

Chrysomyxa pirolata - spruce cone rust

Damping off disease - several fungal spp.

Phaeolus schweinitzii - velvet top fungus causing brown cubical rot

Phellinus pini - red ring rot

Stereum sanguinolentum - a stem decaying fungus 
Non-native Pests

Major pests:

*Heterobasidion annosum - annosus root and butt rot

\section{RED PINE}

Native Pests

Major pests:

Armillaria ostoyae - Armillaria root rot

\section{Lesser pests:}

Dioryctria abietivorella - fir coneworm

Hylobius warreni - Warren rootcollar weevil

Monochamus scutellatus - whitespotted sawyer beetle

Neodiprion nanulus nanulus - red pine sawfly

Pissodes strobi - white pine weevil

Damping off disease - several fungal spp.

Fomitopsis pinicola - red belt fungus (causes a brown rot)

Lophodermella concolor - pine needle cast

Phellinus pini - red ring rot

Sphaeropsis sapinea - Sphaeropsis blight

Lepus americanus - snowshoe hare

\section{Non-native Pests}

Major pests:

Hylobius abietis - large pine weevil

Gremmeniella abietina - scleroderris canker disease

Heterobasidion annosum - annosus root and butt rot

Sirococcus conigenus - Sirococcus shoot blight

\section{Lesser pests:}

**Acantholyda erythrocephala - pine false webworm

Hylobius radicis - pine root collar weevil

* Rhyaciona buoliana - European pine shoot moth

*Tomicus piniperda - pine shoot beetle

Atropellis tingens - a branch, stem and blight fungal disease

Lophodermium seditiosum - a pine needle cast disease

\section{SCOTS PINE}

Native Pests

Major pests:

Choristoneura pinus - jack pine budworm

Dendroctonus ponderosae - mountain pine beetle

Armillaria ostoyae - Armillaria root rot

Lepus americanus - snowshoe hare 


\section{Lesser pests:}

Diprion sawfly spp. - defoliating sawflies

Hylobius warreni - Warren rootcollar weevil

Monochamus scutellatus - whitespotted sawyer beetle

Neodiprion sawfly spp. - defoliating sawflies

Pissodes strobi - white pine weevil

Pissodes terminalis - lodgepole terminal weevil

Cronartium coleosporioides - stalactiform blister rust

Cronartium comandrae - comandra blister rust

Damping off disease - several fungal spp.

Endocronartium harknessii - western gall rust

Lophodermella concolor - pine needle cast

Phaeolus schweinitzii - velvet top fungus causing brown cubical rot

Phellinus pini - red ring rot

Erethizon dorsatum - porcupine

\section{Non-native Pests}

Major pests:

Hylobius abietis - large pine weevil

Gremmeniella abietina - scleroderris canker disease

Heterobasidion annosum - annosus root and butt rot

\section{Lesser pests:}

**Acantholyda erythrocephala - pine false webworm

*Tomicus piniperda - pine shoot beetle

*Hylobius radicis - pine root collar weevil

Cronartium flaccidum - pine stem rust (resin-top disease)

Lophodermium seditiosum - a needle cast disease

Melampsora pinitorqua - pine twisting rust (of shoots)

Peridermium pini - stem rust fungus

Phacidium infestans - white snow mould

Sparassis crispa - a root parasite fungus causing brown rot

* Sphaeropsis sapinea - sphaeropsis blight

Strasseria geniculata - a shoot tip fungal disease of conifer seedlings

\section{ASPEN AND HYBRIDS}

\section{Native Pests}

Major pests:

Malacosoma disstria - forest tent caterpillar

Armillaria spp. - Armillaria root rot species

Hypoxylon mammatum - Hypoxylon canker disease

Peniophora polygonia - Peniophora decay of stems

Phellinus tremulae - aspen trunk rot 


\section{Lesser pests:}

Choristoneura conflictana - large aspen tortrix

Operophtera bruceata - Bruce spanworm

Saperda calcarata - poplar borer

Ganoderma applanatum - white mottled trunk and butt rot

Marssonina brunnea f. sp. trepidae - Marssonina leaf blight

Melampsora albertensis - leaf rust of aspen

Venturia macularis - aspen shoot and leaf blight

\section{Non-native Pests}

Major pests:

Xanthomonas populi - bacterial canker and dieback disease

\section{Lesser pests:}

*Lymantria dispar - gypsy moth

Marssonina castagnei - Marssonina leaf spot disease

Melampsora larici-tremulae - a leaf rust disease

Melampsora pinitorqua - a leaf rust disease on aspen; also called pine twisting rust

\section{HYBRID POPLARS (COTTONWOODS AND HYBRIDS)}

\section{Native Pests}

\section{Major pests:}

Armillaria spp. - Armillaria root rot species

\section{Lesser species:}

Aceria parapopuli - poplar bud gall mite

Chrysomela scripta - cottonwood leaf beetle

Malacosoma disstria - forest tent caterpillar

Cryptorhynchus lapathi - poplar and willow borer

Ganoderma applanatum - white mottled trunk and butt rot

Linospora tetraspora - Linospora leaf blight

Melampsora occidentalis - leaf rust of cottonwood and poplar hybrids

Septoria populicola - Septoria leaf blight

Venturia populina - poplar leaf and shoot blight

\section{Non-native Pests}

Major pests:

Xanthomonas populi - bacterial canker and dieback disease

*Melampsora medusae - leaf rust disease

*Septoria musiva - Septoria canker disease

\section{Lesser pests:}

**Leucoma salicis - satin moth

*Marssonina brunnea f. sp. brunnea - leaf spot fungal disease

Melampsora allii-populina - a leaf rust disease

Melampsora larici-populina - a leaf rust disease

Septoria populi - a leaf blotch disease

Septotinia populiperda - Septotinia leaf blotch disease 
A form for request for approval to reforest with planting stock not meeting requirements (modified from Anon. 1995.)

Seed/Vegetative Material Use Variance Request

\section{REQUESTED BY}

AGENCY NAME:

DIVISION:

MAILING ADDRESS:

CITY: PROV:

PHONE: ( ) FAX: ( ) POSTAL CODE:

CONTACT (Print Name):

\section{SEEDLING REQUEST INFORMATION}

REQUEST ID:

OTHER REQUEST ID(s):

LOT NUMBER: GENETIC CLASS/ SEED ORCHARD CLASS:

FOREST DISTRICT:

REQUESTED AMOUNT:

PLANTING SEASON/YR:

\section{PLANTING SITE}

LATITUDE (degrees/minutes):

SEED ZONE (s):

NATURAL REGION:

NATURAL SUBREGION: (thousands of trees)

ELEVATION (metres): Mean Minimum ECOSITE: LOCATION:

\section{DEPLOYMENT}

REFORESTATION USE: Operational PLANTATION DESIGN:

OTHER MATERIAL TO BE DEPLOYED ON BLOCK:

\section{REASONS FOR REQUEST}

VARIANCE REQUEST TYPE: Limited Use Restricted Use:

\section{SUBMITTED BY}

NAME (Print Name):

Signature:

SEED/VEGETATIVE MATERIAL USE APPROVAL

APPROVED: YES

Remarks:
TITLE:

DATE:

APPROVED BY (Print Name):

Signature: DATE: 


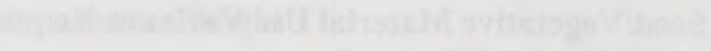

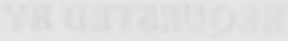
(7)

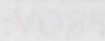

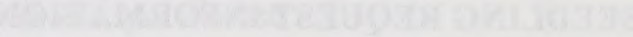

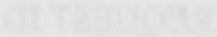

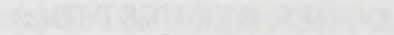

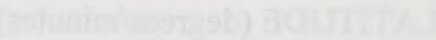
$4(32)^{2}$

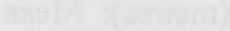





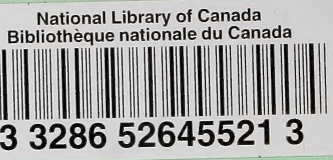

